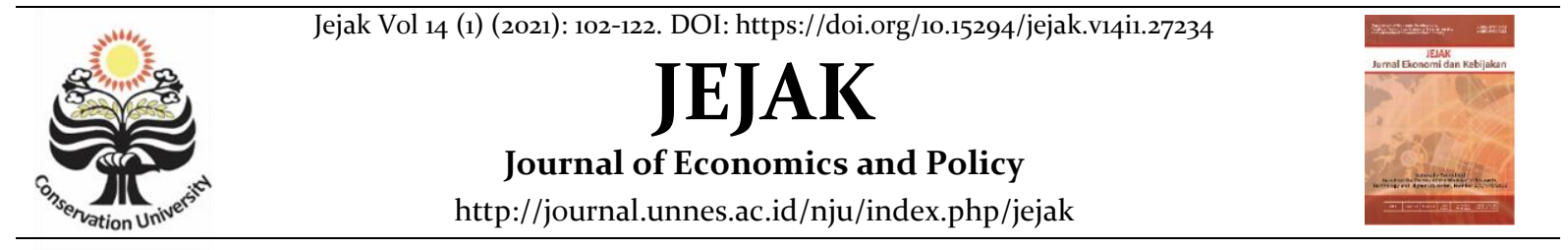

\title{
Asymmetrical Exchange Rates Effect on Indonesia's Trade Balance in Tourism
}

\author{
Akbar Maulana ${ }^{1},{ }^{2 \varpi}$ Taufiq Carnegie Dawood, ${ }^{3}$ Teuku Zulham \\ 'Student at Magister of Economics, Faculty of Economics and Business, \\ Syiah Kuala University, Banda Aceh, Indonesia. \\ 2,3Lecturer at Department of Economc Development, Faculty of Economics and Business, \\ Syiah Kuala University, Banda Aceh, Indonesia.
}

Permalink/DOI: https://doi.org/10.15294/jejak.v14i1.27234

Received: December 2020; Accepted: January 2021; Published: March 2021

\begin{abstract}
The main objective of this research is to analyze the effect of depreciation and real exchange rate appreciation on Indonesia's tourism trade balance bilaterally against Australia, China, Japan, Malaysia, and Singapore. Such analysis on bilateral relations have never been studied for developing markets countries, namely Indonesia. This study uses a linear ARDL approach and a nonlinear ARDL approach with the dependent variable on the tourism trade balance and the real exchange rate as independent variables. Income, foreign direct investment (FDI), and natural disasters as control variables. The empirical results show that Chinese and Japanese tourists respond positively to the depreciation in the real currency rate of exchange, thereby increasing Indonesia's tourism trade balance. Nonlinear ARDL shows that the relation concerning the real rate of exchange plus the balance of trade is non-symmetrical with respect to China and Japan, while Australia, Malaysia, and Singapore are symmetrical. These results suggest that the government should formulate policies to increase tourist visits from China and Japan. Further empirical results also found a J-curve pattern in Indonesia-China and Indonesia-Japan.
\end{abstract}

Key words : Tourism Trade Balance, Real Exchange Rate, Nonlinear ARDL, J-curve

How to Cite: Maulana, A., Dawood, T., \& Zulham, T. (2021). Asymmetrical Exchange Rates Effect on Indonesia's Trade Balance in Tourism. JEJAK: Jurnal Ekonomi dan Kebijakan, 14(1). doi:https://doi.org/10.15294/jejak.v14i1.27234

\footnotetext{
Corresponding author: Taufiq Carnegie Dawood

Address: Faculty of Economics and Business,

Syiah Kuala University

p-ISSN 1979-715X

E-mail: taufiq.dawood@unsyiah.ac.id

e-ISSN 2460-5123
} 


\section{INTRODUCTION}

The tourism sector is the fastest growing service sector in recent years. In 2018, tourism growth grew 3.9 percent, which is above the global economic growth of 3.2 percent. Tourism also contributed 10.4 percent of the gross domestic product (GDP) and 10 percent to employment globally. In 2019, the World Travel and Tourism Council (WTTC) predicted the tourism sector to grow by 4 percent and attract international tourist arrivals as much as 1.4 billion people (World Travel \& Tourism Council - WTTC, 2019).

The tourism sector is very important for the ASEAN region. This is because tourism sector, on average, grew by 5 percent per year. Furthermore in 2018, ASEAN was able to overtake the Oceania region as second position for tourism with contribution to GDP amounting to 12.4 percent. In addition, there are several factors for the rapid growth of tourism in ASEAN such as geographical location adjacent to China which is the largest outbound market, adequate infrastructure, good connectivity and competitive price. If these factors can be increased, it is expected that in the future 1 out of 10 dollars or about USD 782 billion will enter the ASEAN tourism sector (WTTC, 2016).

Indonesia is a large country and is one of the favorite destinations of foreign tourists in the ASEAN region. The total area of Indonesia is $5,194,143 \mathrm{~km}^{2}$, of which two-thirds of the area is ocean and consists of 16,056 islands (Indonesian Central Statistics Agency, 2019). In addition, in Indonesia, there are 13 world heritages consisting of 4 natural heritages, 4 cultural heritages and 5 intangible Cultural works. But Indonesia has not been able to utilize these potentials to the fullest. Compared to other ASEAN countries, Indonesia's tourism sector's contribution to GDD is very low; approximately 6 percent in 2018. This is shown in figure.

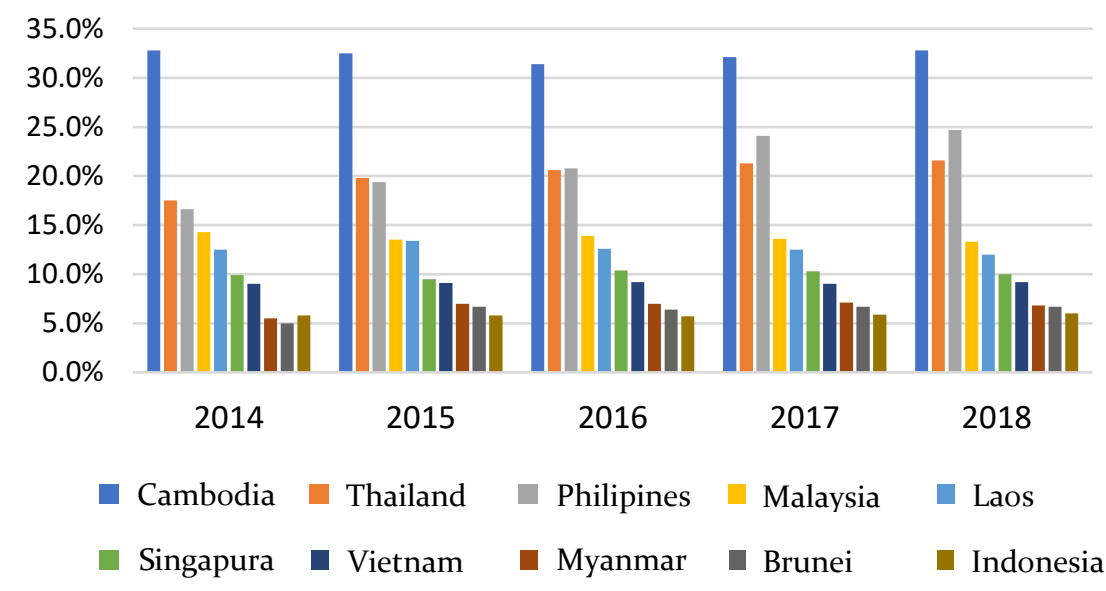

Figure 1. ASEAN countries Tourism GDP contribution 2014-2018

In 2018 Indonesia suffered a trade balance deficit of USD 8.4 billion (Indonesian Central Statistics Agency, 2019). The deficit is the largest in history since Indonesia's independence. Non-oil trade Surplus fell by 81 percent from USD 20.4 billion in 2017 to USD 3.9 billion in 2018. The continuation of non-oil trading surplus decline is the main cause of trade balance deficit. On the other hand, the manufacturing sector contributed to the economy by less than 20 percent with growth rate tends to slow by 4.07 percent. This should be a serious concern for the Government to find alternative sectors in an effort to overcome the trade balance deficit so as not to widen in the absence of global economic certainty, and to avoid the occurrence of early deindustrialization. One alternative that can be done is encouraging the tourism sector. The 
following chart shows non-oil and oil-trade

balance:

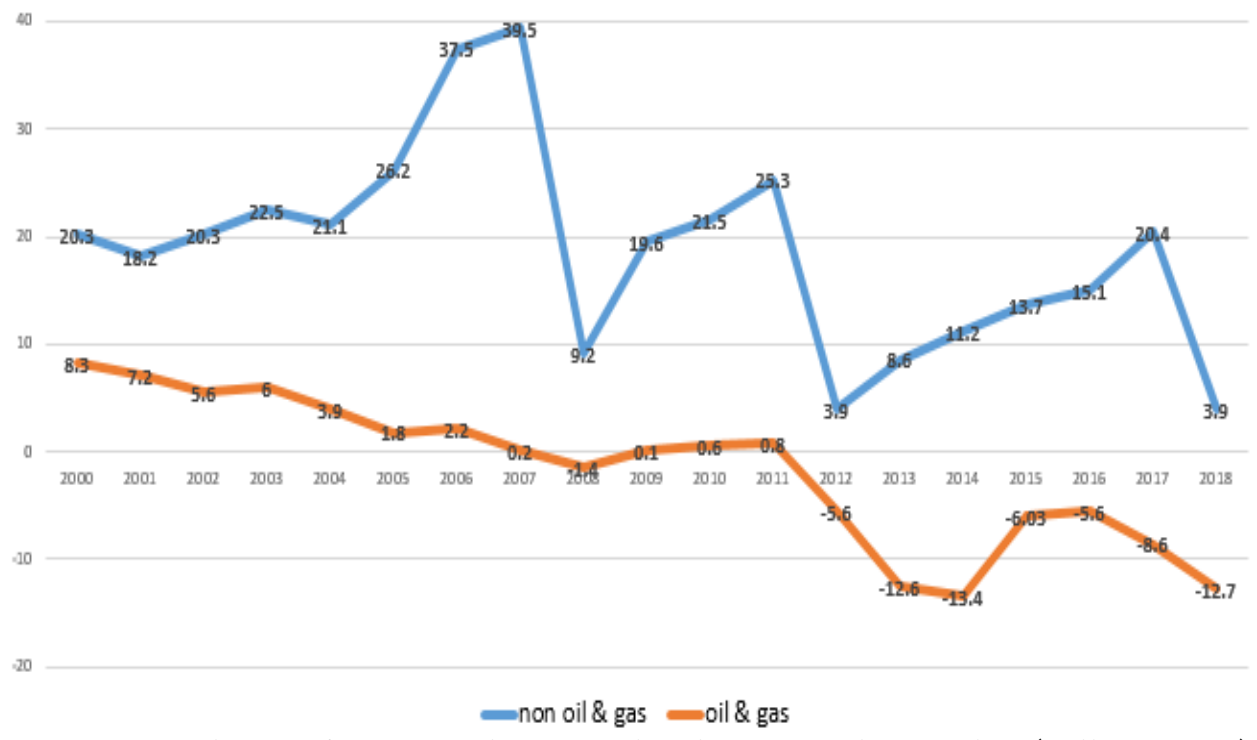

Figure 2. Indonesia's Non-Oil-Gas and Oil-Gas Trade Surplus (Billion USD)

The tourism sector has a bright outlook for the Indonesian economy. In the period 2014-2018, the growth of foreign tourists visit to Indonesia averaged 14 percent annually (Indonesian Central Statistics Agency, 2019). In 2018, the number of foreign tourists which visited Indonesia amounted to 15.8 million, which increased from the previous year. Malaysia is the largest contributor to foreign tourists with 2.5 million visits or 15.8 percent of the total global tourists visit to Indonesia in 2018. Followed by Chinese tourists 2.13 (13.5 percent) and Singapore 1.7 million (11.18 percent) under Malaysia (Indonesian Central Statistics Agency, 2019). Although the Government is striving to increase tourists ' visits from China, Malaysian tourists still dominate the visit to Indonesia. With the increasing number of foreign tourist each year, this makes foreign tourist visits as the heart and foundation of the tourism Industry (Nash, 1981; Tribe, 2009). Considering the increasing trend of foreign tourist visits, the governments at all levels and other stakeholders need to take a larger role to make tourism as the engine of future economic growth. Here are five countries charts with the biggest tourist visit to Indonesia in the last five years:

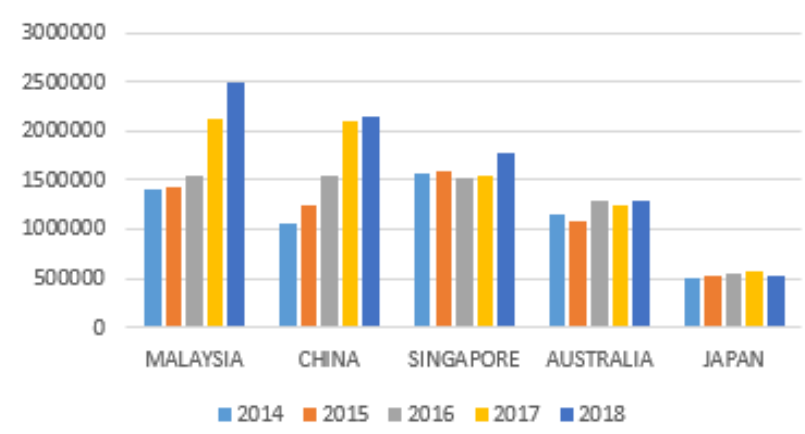

Figure 3. 5 largest Inbound tourist countries to Indonesia 2014-2018

The government can make a number of policies to overcome the trade balance deficit. One of the economic policies that can be used to overcome or reduce the trade deficit is the exchange rate (Bahmani-Oskooee \& Hegerty, 2010; Dogru, Isik \& Sirakaya-Turk, 2019). The Marshall-Lerner condition shows the condition in which a country can correct its trade balance deficit within the long-term through currency depreciation (Bahmani-Oskooee, 1985). This causes imports to become expensive following decreasing demand after depreciation and the volume of exports increases due to changes in relative prices. 
Magee, (1973) argues that after currency depreciation occurs, the trade balance does not improve immediately. However, there is an adjustment of economic behavior to stakeholders, causing the trade balance to deteriorate early because imported goods become expensive after depreciation. In this condition, the market will adjust consumer demand for export and import goods. Imports became costly followed by declining demand and increased export due to the cheap price (Bahmani-Oskooee, Halicioglu \& Hegerty, 2016). Therefore, trade balance will begin to improve in the short-term or long-term forming a sloped-curve or J-curve in international trade theory (Magee, 1973; Bahmani-Oskooee, 1985; Rose \& Yellen, 1989; Bahmani-Oskooee \& Fariditavana, 2016). Studies on the theory of the J-curve have been extensively researched in various countries such as (Bahmani-Oskooee \& Fariditavana, 2016; Ari, Cergibozan \& Cevik, 2019; Bahmani-Oskooee \& Arize, 2019; Bahmani-Oskooee \& Harvey, 2019) found evidence of the J-curve theory. Meanwhile (Rose \& Yellen, 1989; Bahmani-Oskooee, Economidou \& Goswami, 2006; Chi, 2015; Bahmani-Oskooee, Halicioglu \& Hegerty, 2016; Dogru, Isik \& Sirakaya-Turk, 2019) found no evidence of the J-curve theory.

In the tourism sector, the exchange rate plays a role in international tourism demand in any country. The depreciation of local currencies against foreign currencies causes the destination to be costly to have an impact on the outbound tourism decline (Chi, 2015; Dogru, Isik \& Sirakaya-Turk, 2019; Karimi, Khan \& Karamelikli, 2019). However, outbound travelers who continue to travel will spend a greater cost. At the same time, the inbound traveler will spend less on a depreciation destination. This causes the trade balance to deteriorate after depreciation occurs. On the other hand, inbound traveler visits will increase due to currency appreciation, which eventually increases tourism trade balance (Cheng, Kim \&
Thompson, 2013; Chi, 2015; Dogru \& SirakayaTurk, 2018; Karimi, Khan \& Karamelikli, 2019).

Income plays an important role in foreign tourists ' visit to a country's tourist destination (Daniel \& Rodrigues, 2011; Surugiu, Leitão \& Surugiu, 2011; Serra, Correia \& Rodrigues, 2014). The increased Income of tourists is expected to increase international tourism demand. The high national income of a country becomes one of the indicators of a nation's prosperity. Surigao, et al (2011) stated to sustain international traveler's visit then income should be improved.

Eugenio-Martin \& Campos-Soria, (2011), an increase in income at a certain level can increase the decision to make an international holiday and reduce domestic vacations on the other side. With the increased real income then consumers have the discretion to consume various kinds of products comprising tourism (Peng et al, 2015). Therefore, income is a major factor in making decisions for holidaymakers and being an important variable affecting international tourism demand.

Indonesia's growing demand for international tourism will require a large investment. Investment in the tourism sector is a good proxy in support of international tourism demand from the bidding side. Investment in the tourism sector requires enormous capital because it involves the development of tourism infrastructures such as hotels, restaurants, shopping centers, resorts, transportation, entertainment, and recreation venues. Most of the investment sources come from government spending, Domestic Direct Investment (DDI), and Foreign Direct Investment (FDI) (Chen, 2017). From the investment source, FDI is a source of investment that is dynamic and most important in tourism development (Ravinthirakumaran, et al, 2019).

In the current decade, there have been increased cases of natural disasters in Indonesia. Indonesia is geographically located 
in the Ring of Fire, which causes natural disasters such as volcanic eruptions, tsunami, and earthquakes. Not only are natural disasters such as floods, landslides, forest fires that are more caused by human behavior are also common. This natural disaster is often sudden and unavoidable because it is beyond human control (Weisath, Knudsen \& Tonnessen, 2002). In addition, natural disasters can also damage the economic, social, and environmental aspects.

According to Bhati, Upadhayaya \& Sharma, (2016) natural disasters can reduce tourists ' visits to affected areas. For example, earthquakes in Lombok in 2018 reduced tourist visits by 70 percent (BPS). The impact is an enormous effect on the tourism sector in Lombok that requires extra effort to restore it as it was originally. Lombok itself is a favorite destination for tourists and earthquakes that can affect both the provincial and national tourist visits. So that natural disasters can be said to have a negative influence on the tourism sector (Mazzocchi \& Montini, 20o1; Huang \& Min, 2002).

Some studies related to exchange rate and tourism have been conducted before. Dogru, Isik \& Sirakaya-Turk, (2019), analyzes the rate of exchange and the balance of tourism relating to the United States with Canada, Mexico, with the UK. It was found that currency depreciation did not give an immediate worsening effect towards the U.S. tourism balance of trade as stated by J-curve theory. So J-curve theory suggested by Magee, (1973); Bahmani-Oskooee, (1985); Rose \& Yellen, (1989); Bahmani-Oskooee \& Fariditavana, (2016) does not happen in this case. In contrast, the U.S. tourism balance of trade instantly improved after depreciation, which supported the Marshall-Lerner condition, that the longterm trade balance deficit could be corrected through currency depreciation (Branson, 1972;
Bahmani-Oskooee, 1985). The findings revealed that the depreciation and appreciation of the currency had the same effect for the U.S. tourism balance of trade with respect to Canada plus the UK. While appreciation has a different effect on the trade balance of tourism between the United States and Mexico.

Study by Karimi, Khan \& Karamelikli, (2019), analyzed the asymmetric effect of the exchange rate against foreign tourists visiting Malaysia. It was found that appreciation and depreciation of currencies would reduce the number of foreign arrivals in the long term. Appreciation increases the price while depreciation does not affect the local price offered to the foreign tourists in the long run. In addition, the study of the influence of exchange rates on the tourism sector is also conducted by Agiomirgianakis, Bertsatos and Tsounis, (2018); Irandoust, (2019); Loganatan et al., (2019); Tung, (2019), was found that the exchange rate influenced the tourism sector. While the study of Tang et al., (2016); Wang \& Tang, (2018) found no exchange rate influence towards the tourism sector.

In addition, the study conducted by (Dogru, Isik \& Sirakaya-Turk, 2019) also analyzed the effect of depreciation and the rate of exchange appreciation towards the US trade balance of tourism against Mexico, Canada, and the United Kingdom. The results show that the depreciation of the US dollar increases the US tourism trade balance with the three partners. However, while the appreciation of the U.S. dollar deteriorates the U.S. bilateral tourism trade balance with Canada and the U.K., it does not ultimately affect the U.S. bilateral tourism trade with Mexico in the long term. The study conducted by Ongan \& Özdemir, (2018); Işik, Radulescu \& Fedajev, (2019) also confirms the findings which are concur with the study by Dogru, Isik \& Sirakaya-Turk, (2019) which states that the rate exchange weakening will 
enhance the tourism trade balance in the long term.

This study also examines the J-curve pattern, where the J-curve phenomenon is formed when the depreciation of the exchange rate worsens the trade balance in the short run but improves it in the long run. Several studies related to the J-curve phenomenon have been reported with different results. BahmaniOskooee \& Fariditavana, (2016); Ari, Cergibozan \& Cevik, (2019); Bahmani-Oskooee \& Arize, (2019); Bahmani-Oskooee \& Harvey, (2019) found confirmation for the theory of the J-curve. While Rose \& Yellen, (1989); BahmaniOskooee, Economidou \& Goswami, (2006); Dogru, Isik \& Sirakaya-Turk, (2019) found no evidence for the J-curve theory.

This research contributed to the literature in tourism which presents the empirical influence of the exchange rate effect on the tourism trade balance. Unlike previous research that tends to use tourist visits, the current analysis focuses on the tourism trade balance. Previous research limitations derived from a) analyses using aggregate data and b) assume the exchange rate is symmetrical. In fact, the aggregate data is unable to obtain a bilateral tourism policy to glance at the country with a large outbound market. Assuming the exchange rate is symmetrical is less precise because depreciation plus appreciation may have a different influence on the tourism trade balance. The author's knowledge, this study was the first to analyze the asymmetric influence of the exchange rate on the tourism trade balance for Indonesia which is the emerging market in the Asia region.

The remainder of the study was arranged in the following order. Part 2 presents a literature research method. Part 3 provides an empirical framework used in this study. Finally, the last section concludes the paper and provides some policy recommendations.

\section{METHOD}

This study uses tourism trade balance data as measured by foreign tourists (inbound) visits to Indonesia minus the domestic tourist (outbound) visit outside Indonesia. The country partners in this study are IndonesiaAustralia, Indonesia-China, Indonesia-Japan, Indonesia-Malaysia, and Indonesia-Singapore.

These countries were chosen because they were the 5 countries with the largest foreign tourist visits to Indonesia in the last 5 years. Income is gauged based on the gross domestic product in real terms (GDP). Foreign Direct Investment (FDI) is measured by the flow of FDI to the tourism sector. Disasters are measured based on natural disasters occurring in Indonesia. And the exchange rate is measured based on Indonesia-Australia, Indonesia-China, Indonesia-Japan, IndonesiaMalaysia, and Indonesia-Singapore bilateral real rate of exchange.

Tourism trade balance data is derived from the Indonesian statistical Centre (BPS) and CEIC Data. Real GDP as a proxy income is obtained from Knoema. FDI is obtained from the Indonesian Capital Investment Coordinating Board (BKPM). Natural disasters are obtained from Indonesia's National disaster (BNPB) agency and real exchange rates are obtained from the Pacific Exchange Rate Service (PERS) and CEIC Data.

The study used the Autoregressive Distributed Lag (ARDL) and nonlinear Autoregressive Distributed Lag (NARDL) approaches developed by Shin, $\mathrm{Yu}$ and Greenwood-Nimmo, (2014) and Pesaran, Shin and Smith, (2001) to test nonlinear relations of rates of exchange with tourism balance of trade. The use of a nonlinear ARDL model is based on Keynes's argument in Karimi, Khan \& Karamelikli, (2019), that declining tendency changes often occur suddenly and sharply, 
whereas there is no sharp and sudden turning point when tendencies upward on the trading cycle. Po \& Huang in Meo et al, (2018) also state structural changes and volatility in the short term cannot be investigated through linear models. The following estimation Model is employed with objective to evaluate the relation concerning the real rate of exchange with the tourism balance trade which is based on the Pesaran, Shin, \& Smith (2001).

$$
\begin{aligned}
& \text { TBTi, } t=\beta_{o}+\beta_{1} Y_{I N D, t}+\beta_{2} Y_{i, t}+\beta_{3} F D I_{i, t}+\beta_{4} N D S_{i, t}+ \\
& \beta_{5} R E R_{i, t}+\varepsilon_{t}
\end{aligned}
$$

Next the logarithmic shape of the above equation as follows:

$\operatorname{lnTBTi}, t=\beta_{o}+\beta_{1} \ln Y_{I N D, t}+\beta_{2} \ln Y_{i, t}+\beta_{3} \ln F D I_{i, t}+$ $\beta_{4} \ln N D S_{i, t}+\beta_{5} \ln R E R_{i, t}+\varepsilon_{t}$

Where $\ln \mathrm{TBT}_{\mathrm{i}, \mathrm{t}}$ is the arrival rate of the country tourists $\mathrm{i}$ who enter Indonesia minus with the departure of Indonesian tourists to the same country; $\operatorname{lnYidn}, \mathrm{t}$ and $\ln \mathrm{Y}_{\mathrm{i}, \mathrm{t}}$ is an Indonesian income and its trade counterpart country at the time of $t ; F_{i, t}$ is a foreign investment into the Indonesian tourism sector at the time of $t, \operatorname{lnNDS}_{\mathrm{i}, \mathrm{t}}$ is the frequency natural disaster that occurred in Indonesia at the time of $t$; And $\ln R E R_{i, t}$ is a bilateral real exchange rate between Rupiah and the currency of its partner country at the time of $\mathrm{t}$.

Model specifications in this study based on the study of Bahmani-Oskooee and Fariditavana, (2016); Bahmani-Oskooee, Halicioglu \& Hegerty, (2016); Dogru, Isik \& Sirakaya-Turk, (2019). Here are the equation models:

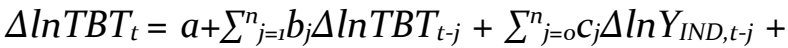
$\sum_{j=o}^{n} d_{j} \Delta \ln Y_{i, t-j}+\sum_{j=o}^{n} e_{j} \Delta \ln F D I_{t-1}+\sum_{j=o}^{n} f_{j} \Delta \ln N D S_{t-1}$ $+\sum_{j=o}^{n} g_{j} \Delta \ln R E R_{t-1}+\delta_{1} \ln T B T_{t-1}+\delta_{2 l n} Y_{I N D, t-1}+$ $\delta_{3 l n} Y_{i, t-1}+\delta_{4 l n} F D I_{t-1}+\delta_{5} \ln N D S_{t-1}+\delta_{6 l n} R E R_{t-1}+\varepsilon_{t}$

The cointegration test is used to determine the long-term relationship between variables. If it is cointegrated, it means that there is a stable relationship in the long term. Conversely, if there is no cointegration between variables, it means that there is no long-term linkage. The cointegration test in the ARDL model uses the F-bound testing approach Shin, Yu, \& Greenwood-Nimmo, (2014) and Pesaran, Shin, \& Smith, (2001) to test the cointegration of all variables.

In the test, if the F-statistic value is below the lower bound value, it is concluded that there is no cointegration and vice versa if the Fstatistic is above the upper bound value, it is concluded that there is cointegration. However, if the F-statistic is between the lower and upper bound values, the result is inconclusive. The following is the hypothesis in F bounds testing: $\mathrm{H}_{\mathrm{o}}=\theta_{1}=\theta_{2}=\theta_{\mathrm{n}}=\mathrm{o}$; no long-term relationship (no cointegration)

$\mathrm{H}_{1} \neq \theta_{1} \neq \theta_{2} \neq \theta_{\mathrm{n}} \neq \mathrm{o}$; there is a long-term relationship (cointegration)

In the equation (3), if the short- and longterm coefficient of $g_{j}$ and $\delta_{6}$ positive then the depreciation of the RER improves Indonesia's tourism trade balance in the short term and long term conversely if the negative coefficient then the depreciation of the RER deteriorates the Indonesian tourism trade balance in the short and long term.

The effect of changes in exchange rate may not be symmetrical when the trade balance responds to appreciation and depreciation differently. To address the issue, this study followed Bahmani-Oskooee \& Fariditavana (2016) where $\triangle \ln R E R$ exchange rate includes positive and negative changes. Furthermore, the Rupiah appreciation is denoted by POS and the depreciation of Rupiah denoted by NEG as follows:

$P O S=\Delta \ln R E R^{+}{ }_{j}=\sum_{j=1}^{n} \Delta \ln R E R^{+}{ }_{j}=\sum_{j=1}^{n} \max$ $\left(\triangle \ln R E R_{j}, \mathrm{O}\right)$ 
$N E G=\Delta \ln R E R_{j}^{-}=\sum_{j=1}^{n} \Delta \ln R E R_{j}^{-}=\sum_{j=1}^{n} \min$ $\left(\triangle \ln R E R_{j}, \mathrm{O}\right)$

Following Shin, $\mathrm{Yu}$ and GreenwoodNimmo, (2014), lnRER in the equation (3) is replaced by a partial number of POS and NEG that have been determined by the equation (4) and (5). By building the POS and NEG variables, Shin, et al (2014) named this model with nonlinear ARDL. The specifications of the nonlinear ARDL model in the study consisted of five equations as follows:

$$
\begin{aligned}
& \Delta \operatorname{lnTBT_{t}=} a+\sum_{j=1}^{n} b_{j} \Delta \operatorname{lnTBT_{t-j}+} \\
& \sum_{j=0}^{n} c_{j} \Delta \ln Y_{I N D, t-j}+\sum_{j=0}^{n} d_{j} \Delta \ln Y_{i, t-j}+ \\
& \sum_{j=0}^{n} e_{j} \Delta \ln F D I_{t-1}+\sum_{j=0}^{n} f_{j} \Delta \ln N D S_{t-1}+ \\
& \sum_{j=0}^{n} g_{j}^{+} \Delta P O S_{t-j}+\sum_{j=0}^{n} g_{j}^{-} \Delta N E G_{t-j}+ \\
& \delta_{1} \ln T B T_{t-1}+\delta_{2} \ln Y_{I N D, t-1}+\delta_{3} \ln Y_{i, t-1}+ \\
& \delta_{4} \ln F D I_{t-1}+\delta_{5} \ln N D S_{t-1}+\delta_{6}^{+} P O S_{t-1}+ \\
& \delta_{6}^{-} N E G_{t-1}+\varepsilon_{t}
\end{aligned}
$$

Similarly linear ARDL model, in the nonlinear ARDL model we also use the F-bound test approach Shin, Yu \& Greenwood-Nimmo, (2014) plus Pesaran, Shin \& Smith, (2001) to test the cointegration of all variables. Then, to test the exchange rate asymmetry in the long run we used the Wald test. To see the long-run exchange rate asymmetry, we evaluated the null hypothesis of the long-term symmetric test, namely $\beta^{+}=\beta^{-}$where $\beta^{+}=-\delta_{6}^{+} / \delta_{1}$ dan $\beta^{-}=$ $-\delta_{6}^{-} / \delta_{1}$. Furthermore, to obtain the long-term coefficient from the nonlinear ARDL estimation results is defined by $\hat{\beta}=-\hat{\theta} / \hat{\rho}$ by following the study of Shin et al., (2014). Then, to identify the j-curve phenomenon we follow BahmaniOskooee and Fariditavana, (2016) if the coefficient $g_{j}^{-}$is negative or not statistically significant while the coefficient $\delta_{6}^{-}$- is positive and significant it can be concluded that there is a j-curve phenomenon.

In the equation (6), if the short-term coefficient $g_{j}^{-} \Delta N E G$ and long-term $\delta_{6}^{-} N E G$ significantly positively signifies that the depreciation of the RER increases Indonesia's tourism trade balance in the short and long term. Whereas if the short-term coefficient $g_{j}^{+} \triangle P O S$ and long-term $\delta_{6}^{+} P O S$ positive indicates that the RER appreciation worsens Indonesia's trade balance in the short and long term.

\section{RESULT AND DISCUSSION}

The data stationary test needs to be done before this research is carried out. The purpose of the stationary test is to see whether the data for each variable is around the mean with fluctuations independent of previous variances. If the data used is not stationary included in the equation it will result in a spurious regression. There are various methods for conducting data stationarity tests such as Dickey-Fuller, ADF (Augmented Dickey-Fuller Test), PP (PhilipPerron), and KPSS (Kwiatkowski Philips Schmidt Shin).

In implementing the ARDL model, the data used must not be stationary in second difference I (2), because it will result in an invalid regression. So that the data used must be stationary at level I(o) or first difference I(I) or a mixture of $\mathrm{I}(\mathrm{O})$ and $\mathrm{I}(\mathrm{1})$. Therefore, the Augmented Dickey-Fuller (ADF) and PhillipsPerron (PP) unit root test were used in this study to ensure that the data were not stationary in second difference I(2). The results of the root unit test are shown in table 1. 
Table 1. Unit Root Test Results

\begin{tabular}{|c|c|c|c|c|c|}
\hline ADF (AUSTRALIA) & & & PP (AUSTRALIA) & & \\
\hline Variable & Intercept & $\begin{array}{c}\text { Intercept and } \\
\text { Trend }\end{array}$ & Variable & Intercept & $\begin{array}{c}\text { Intercept and } \\
\text { Trend }\end{array}$ \\
\hline LnTBT & -0.93 & -0.72 & LnTBT & -1.69 & -3.33 \\
\hline LnYidn & 0.69 & -2.59 & LnYidn & 0.65 & -2.65 \\
\hline LnYaus & -1.47 & -1.45 & LnYaus & -1.74 & -1.39 \\
\hline LnFDI & $-4.29^{* * *}$ & $-6.83^{* * *}$ & LnFDI & $-4 \cdot 31^{* *}$ & $-6.78^{* *}$ \\
\hline LnNDS & -2.00 & -1.67 & LnNDS & $-3.41^{*}$ & $-5.02^{* *}$ \\
\hline LnRER & $-3.72^{* * *}$ & $-3.85^{* *}$ & LnRER & $-3 \cdot 71^{* *}$ & $-3.86^{*}$ \\
\hline LnRER $^{+}$ & -1.96 & $-3.39^{*}$ & LnRER $^{+}$ & -1.97 & -3.36 \\
\hline LnRER- & -2.48 & -1.84 & LnRER- & $-3.19^{*}$ & -1.52 \\
\hline$\Delta \ln T B T$ & $-2.63^{*}$ & -2.44 & $\Delta \ln T B T$ & $-15.58^{* *}$ & $-15.94^{* *}$ \\
\hline$\Delta \operatorname{lnYidn}$ & $-8.27^{* * *}$ & $-8.22^{* * *}$ & $\Delta \operatorname{lnYidn}$ & $-8.28^{* *}$ & $-8.22^{* *}$ \\
\hline$\Delta \operatorname{lnYaus}$ & $-8.22^{* * *}$ & $-8.35^{* * *}$ & $\Delta \operatorname{lnYaus}$ & $-8.21^{\star *}$ & $-8.38^{* *}$ \\
\hline$\Delta \operatorname{lnFDI}$ & $-9 \cdot 35^{* * *}$ & $-9 \cdot 32^{* * *}$ & $\Delta \operatorname{lnFDI}$ & $-19.29^{* *}$ & $-20.64^{* *}$ \\
\hline$\Delta \operatorname{lnNDS}$ & $-5 \cdot 57^{* * *}$ & $-5.67^{* * *}$ & $\Delta \operatorname{lnNDS}$ & $-18.56^{* *}$ & $-20.07^{* *}$ \\
\hline$\Delta \ln R E R$ & -11.64 & $-11.56^{* * *}$ & $\Delta \operatorname{lnRER}$ & $-11.64^{* *}$ & $-11.56^{* *}$ \\
\hline$\Delta \operatorname{lnRER}{ }^{+}$ & $-8.3^{* * *}$ & -8.44 & $\Delta \operatorname{lnRER} R^{+}$ & $-8.31^{* *}$ & $-8.44^{* *}$ \\
\hline$\Delta \operatorname{lnRER}{ }^{-}$ & $-10.45^{* * *}$ & $-11.47^{* * *}$ & $\Delta \operatorname{lnRER}{ }^{-}$ & $-10.36^{* *}$ & $-11.76^{* *}$ \\
\hline ADF (CINA) & & & PP (CINA) & & \\
\hline LnTBT & 1.65 & -0.29 & LnTBT & -1.55 & $-4.35^{* *}$ \\
\hline LnYidn & 0.69 & -2.59 & LnYidn & 0.65 & -2.65 \\
\hline LnYcin & $-4.06^{* * *}$ & 1.58 & LnYcin & -2.86 & 0.81 \\
\hline LnFDI & $-4.29^{* * *}$ & $-6.83^{* * *}$ & LnFDI & $-4 \cdot 31^{* *}$ & $-6.78^{\star *}$ \\
\hline LnNDS & -2.00 & -1.67 & LnNDS & $-3.41^{*}$ & $-5.02^{* *}$ \\
\hline LnRER & -1.76 & -2.12 & LnRER & -1.72 & $-2 . .20$ \\
\hline LnRER $^{+}$ & -1.69 & -2.07 & LnRER $^{+}$ & -1.70 & -2.17 \\
\hline LnRER $^{-}$ & -0.57 & -2.84 & LnRER- & -0.57 & -2.96 \\
\hline$\Delta \ln T B T$ & $-4.19^{* * *}$ & $-11.86^{* * *}$ & $\Delta \ln T B T$ & $-21.59^{* *}$ & $-41.02^{* *}$ \\
\hline$\Delta \operatorname{lnYidn}$ & $-8.27^{* * *}$ & $-8.22^{* * *}$ & $\Delta \operatorname{lnYidn}$ & $-8.28^{* *}$ & $-8.22^{* *}$ \\
\hline$\Delta \ln Y c i n$ & $-4.98^{\star * *}$ & $-5.88^{* * *}$ & $\Delta \ln Y \operatorname{cin}$ & $-4.98^{\star *}$ & $-5.88^{\star *}$ \\
\hline$\Delta \operatorname{lnFDI}$ & $-9 \cdot 35^{* * *}$ & $-9 \cdot 32^{* * *}$ & $\Delta \operatorname{lnFDI}$ & $-19.29^{* *}$ & $-20.64^{* *}$ \\
\hline$\Delta \operatorname{lnNDS}$ & $-5 \cdot 57^{* * *}$ & $-5.67^{* * *}$ & $\Delta \operatorname{lnNDS}$ & $-18.56^{* *}$ & $-20.07^{* *}$ \\
\hline$\triangle \operatorname{lnRER}$ & $-9.05^{* * *}$ & $-9.06^{* * *}$ & $\Delta \ln R E R$ & $-9.07^{* *}$ & $-9.06^{* *}$ \\
\hline$\Delta \operatorname{lnRER}{ }^{+}$ & $-8.05^{* * *}$ & $-8.21^{\star * *}$ & $\Delta \operatorname{lnRER}{ }^{+}$ & $-8.07^{* *}$ & $-8.21^{* *}$ \\
\hline$\Delta \operatorname{lnRER}{ }^{-}$ & $-8.3^{* * *}$ & $-8.27^{* * *}$ & $\Delta \operatorname{lnRER}$ R $^{-}$ & $-8.31^{* *}$ & $-8.26^{* *}$ \\
\hline ADF (JAPAN) & & & PP (JAPAN) & & \\
\hline LnTBT & -1.23 & $-3.99^{* *}$ & LnTBT & $-5.27^{* * *}$ & $-9 \cdot 79^{* * *}$ \\
\hline LnYidn & 0.69 & -2.59 & LnYidn & 0.65 & -2.65 \\
\hline LnYjpn & -0.98 & -2.28 & LnYjpn & -1.08 & -2.47 \\
\hline LnFDI & $-4.29^{* * *}$ & $-6.83^{* * *}$ & LnFDI & $-4.31^{* * *}$ & $-6.78^{* * *}$ \\
\hline LnNDS & -2.00 & -1.67 & LnNDS & $-3.41^{* *}$ & $-5.02^{* * *}$ \\
\hline LnRER & -1.96 & $-3.21^{*}$ & LnRER & -1.81 & -3.17 \\
\hline LnRER $^{+}$ & -0.74 & -2.96 & LnRER $^{+}$ & -0.78 & -3.03 \\
\hline LnRER- & -0.28 & -3.11 & LnRER- & 0.28 & -3.05 \\
\hline$\Delta \ln T B T$ & $-4.88^{* * *}$ & $-4.86^{* * *}$ & $\Delta \operatorname{lnTBT}$ & $-42.47^{* * *}$ & $-42.63^{* * *}$ \\
\hline$\Delta \operatorname{lnYidn}$ & $-8.27^{* * *}$ & $-8.22^{* * *}$ & $\Delta \operatorname{lnYidn}$ & $-8.28^{\star * *}$ & $-8.22^{* * *}$ \\
\hline$\Delta \operatorname{lnYjpn}$ & $-7 \cdot 35^{* * *}$ & $-7 \cdot 30$ & $\Delta \operatorname{lnYjpn}$ & $-7.27^{* * *}$ & $-7.20^{* * *}$ \\
\hline$\Delta \operatorname{lnFDI}$ & $-9 \cdot 35^{* * *}$ & $-9 \cdot 32^{* * *}$ & $\Delta \operatorname{lnFDI}$ & $-19.29^{* * *}$ & $-20.64^{* * *}$ \\
\hline$\Delta \operatorname{lnNDS}$ & $-5 \cdot 57^{* * *}$ & $-5.67^{* * *}$ & $\Delta \operatorname{lnNDS}$ & $-18.56^{* * *}$ & $-20.07^{* * *}$ \\
\hline$\Delta \operatorname{lnRER}$ & $-8.02^{* * *}$ & $-8.08^{* * *}$ & $\Delta \operatorname{lnRER}$ & $-9 \cdot 76^{* * *}$ & $-9.81^{* * *}$ \\
\hline$\Delta \operatorname{lnRER}{ }^{+}$ & $-90.4^{* * *}$ & $-9.02^{* * *}$ & $\Delta \operatorname{lnRER} R^{+}$ & $-9.11^{* * *}$ & $-9 \cdot 10^{* * *}$ \\
\hline$\Delta \operatorname{lnRER^{-}}$ & $-10.02^{* * *}$ & $-10.03^{* * *}$ & $\Delta \ln R^{-}$ & $-10.04^{* * *}$ & $-10.03^{* * *}$ \\
\hline ADF (MALAYSIA) & & & PP (MALAYSIA) & & \\
\hline
\end{tabular}




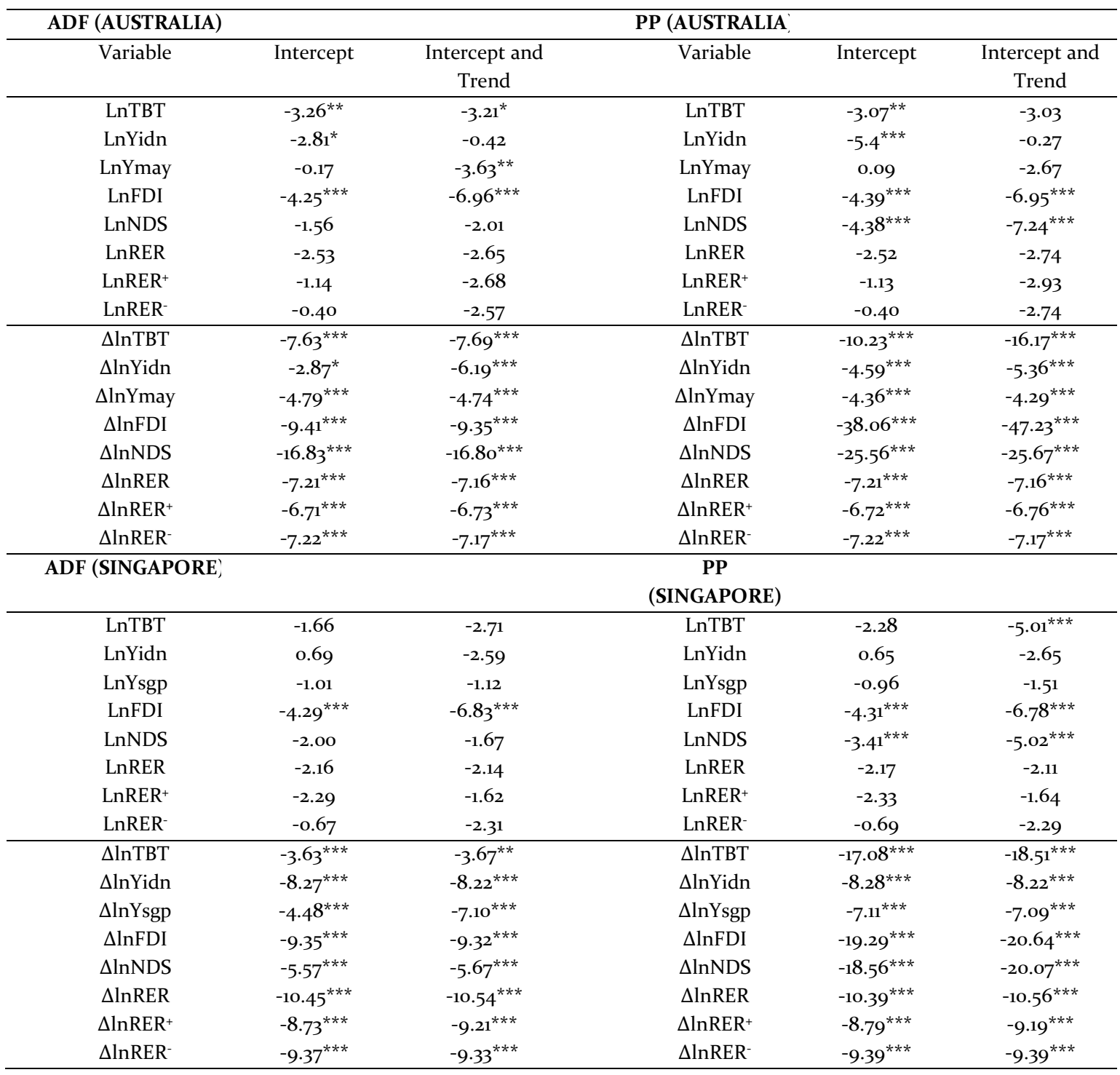

Description: The level of significance * $10 \%,{ }^{* *} 5 \%$ and ${ }^{* * *} 1 \%$.

The results of the unit root test are shown in table 1. From the ADF and PP unit tests it is found that the bilateral real exchange rate, foreign GDP, foreign direct investment in Indonesian sector and the frequency of natural disaster are integrated of order zero $(\mathrm{I}(\mathrm{o}))$. This indicates that these variables are stationary at level, with degrees of freedom ranging from 1 percent up to 10 percent levels of significance. While the remaining variables are found to be non-stationary at level, however these variables are stationary at the first difference. This result indicates that these variables are integrated of order one $(\mathrm{I}(1))$ at significance level of 10 percent. From the unit root test, it is concluded that the degree of integration of the variables employed in this study are mixed stationary data of I(o) and I(1). According to (Pesaran, Shin \& Smith, 2001), this satisfies the requirement to be able to apply the Autoregressive Distributed Lag Model. In determining the maximum lag, a general to specific approach is used based on the Akaike Information Criteria (AIC) to select the appropriate linear ARDL and nonlinear ARDL specifications. Further empirical results of linear and nonlinear ARDL are shown in Tables 2 and 3 . 
Table 2. Linear ARDL

\begin{tabular}{|c|c|c|c|c|c|c|c|c|c|}
\hline & Australia & & & China & & & Japan & & \\
\hline & Variable & Coeff & t-stat & Variable & Coeff & t-stat & Variable & Coeff & t-stat \\
\hline \multirow{12}{*}{ 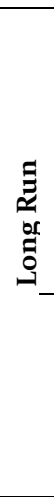 } & Constant & 49.16883 & $4.8 \mathrm{o}^{* * *}$ & Constant & -32901489 & $-7.18^{* * *}$ & Constant & 3982451. & $2.32^{* *}$ \\
\hline & $\ln \mathrm{TBT}_{\mathrm{t}-1}$ & -0.601220 & $-6.37^{* * *}$ & $\ln \mathrm{TBT}_{\mathrm{t}-1}$ & -1.453549 & $-10.07^{* * *}$ & $\ln \mathrm{TBT}_{\mathrm{t}-1}$ & -0.591149 & $-6.49^{* * *}$ \\
\hline & $\operatorname{lnYidn}_{\mathrm{t}-1}$ & 10.58900 & $5.29^{* * *}$ & $\operatorname{lnYidn}_{\mathrm{t}-1}$ & 18055373 & $8.40^{* * *}$ & $\operatorname{lnYidn}_{\mathrm{t}-1}$ & -290012.4 & $3.79^{* * *}$ \\
\hline & $\operatorname{lnYaus}_{\mathrm{t}-1}$ & -18.55498 & $-5.06^{* * *}$ & $\operatorname{lnY} \operatorname{cin}_{t-1}$ & -10340426 & $-8.89^{* * *}$ & $\operatorname{lnYjpn} n_{t-1}$ & -440213.9 & -1.67 \\
\hline & $\operatorname{lnFDI}{ }_{t-1}$ & 0.008872 & 0.33 & $\operatorname{lnFDI}{ }_{t-1}$ & 128550.1 & 1.75 & $\operatorname{lnFDI} I_{t-1}$ & 70661.87 & $3 \cdot 73^{* * *}$ \\
\hline & $\operatorname{lnNDS} S_{t-1}$ & 0.011833 & 0.31 & $\operatorname{lnNDS} S_{t-1}$ & 87786.61 & 1.33 & $\operatorname{lnNDS} S_{t-1}$ & $-7095 \cdot 351$ & -0.78 \\
\hline & $\ln R E R_{t-1}$ & -2842.546 & $-1.86^{*}$ & $\ln R E R_{\mathrm{t}-1}$ & $1.84 \mathrm{E}+\mathrm{o} 8$ & 1.15 & $\ln \operatorname{RER}_{\mathrm{t}-1}$ & -4046836 & -1.37 \\
\hline & LnYidn & 17.61253 & $7.02^{* \star \star}$ & LnYidn & 12421581 & $20.26^{* \star *}$ & LnYidn & -490590.7 & $-3.53^{* * *}$ \\
\hline & LnYaus & -30.86222 & $-6.06^{* * *}$ & LnYcin & -7113918. & $-21.99^{* * *}$ & LnYjpn & -744674.3 & 1.53 \\
\hline & LnFDI & 0.014756 & 0.32 & LnFDI & 88438.78 & 1.71 & LnFDI & 119533.0 & $3.07^{* * *}$ \\
\hline & LnNDS & 0.019681 & 0.31 & LnNDS & 60394.68 & 1.33 & LnNDS & -12002.63 & -076 \\
\hline & LnRER & -4727.966 & $-2.13^{* *}$ & LnRER & $1.26 \mathrm{E}+\mathrm{o} 8$ & 1.14 & LnRER & -6845707 & -1.38 \\
\hline \multirow{35}{*}{ 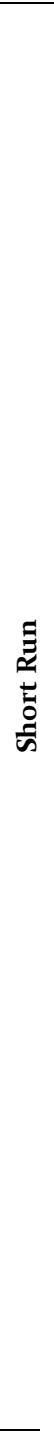 } & $\Delta \ln \mathrm{TBT}_{\mathrm{t}-1}$ & 0.337506 & $3.14^{* * *}$ & $\Delta \ln \mathrm{TBT}_{\mathrm{t}-3}$ & -0.302262 & $-3 \cdot 77^{* * *}$ & $\Delta \ln \mathrm{TBT}_{\mathrm{t}-2}$ & 0.197436 & $2.49^{* *}$ \\
\hline & $\Delta \ln \mathrm{TBT}_{\mathrm{t}-3}$ & 0.352418 & $3.29^{* * *}$ & $\Delta \operatorname{lnYidn}$ & 22798665 & $4.54^{* * *}$ & $\Delta \ln \mathrm{TBT}_{\mathrm{t}-4}$ & 0.582600 & $7 \cdot 49^{* * *}$ \\
\hline & $\Delta \ln \mathrm{TBT}_{\mathrm{t}-4}$ & -11.96087 & $6.88^{* * *}$ & $\Delta \operatorname{lnYidn} n_{t-1}$ & -13336784 & $-3.84^{* * *}$ & $\Delta \operatorname{lnYidn} \mathrm{t}_{-4}$ & -2076361. & $-2.49^{* *}$ \\
\hline & $\Delta \ln \mathrm{TBT}_{\mathrm{t}-7}$ & -0.227390 & $-2.56^{* *}$ & $\Delta \operatorname{lnYidn}_{\mathrm{t}-2}$ & -12167434 & $-2.21^{* *}$ & $\Delta \operatorname{lnYidn}_{\mathrm{t}-5}$ & 3700914. & $3.83^{* * *}$ \\
\hline & $\Delta \operatorname{lnYidn}$ & 13.54670 & $2.31^{* *}$ & $\Delta \operatorname{lnYidn}_{\mathrm{t}-3}$ & 11030894 & $2.91^{* *}$ & $\Delta \operatorname{lnYjpn_{t-6}}$ & -1419824 & $-2.92^{* * *}$ \\
\hline & $\Delta \operatorname{lnYidn}_{\mathrm{t}-\mathrm{I}}$ & -11.71773 & $-1.94^{*}$ & $\Delta \operatorname{lnYidn}_{-5}$ & -8157652 & $-1.87^{*}$ & $\Delta \operatorname{lnFDI}$ & -10245.80 & $-2.02^{* *}$ \\
\hline & $\Delta \operatorname{lnYidn}_{\mathrm{t}-2}$ & 14.14358 & $2 / 59^{* *}$ & $\Delta \operatorname{lnYidn}_{\mathrm{t}-7}$ & 15322805 & $4.96^{* * *}$ & $\Delta \operatorname{lnFDI}_{\mathrm{t}-1}$ & -68805.40 & $-4.83^{* * *}$ \\
\hline & $\Delta \operatorname{lnYidn}{ }_{\mathrm{t}-4}$ & -11.30383 & $-2.22^{* *}$ & $\Delta \operatorname{lnYidn}_{-8}$ & 22737527 & $4.80^{* * *}$ & $\Delta \operatorname{lnFDI}_{\mathrm{t}-2}$ & -54834.35 & $-4.80^{* * *}$ \\
\hline & $\Delta \operatorname{lnYidn}{ }_{t-5}$ & 10.40640 & $2.34^{* *}$ & $\Delta \operatorname{lnYidn}_{\mathrm{t}-9}$ & 13979094 & $3.99^{* * *}$ & $\Delta \ln \mathrm{FDI}_{\mathrm{t}-3}$ & -40456.12 & $-4.10^{* * *}$ \\
\hline & $\Delta \ln Y a u s_{t-1}$ & 12.83630 & $2.26^{* *}$ & $\Delta \operatorname{lnY} \operatorname{cin}$ & 5653110. & $1.99^{*}$ & $\Delta \operatorname{lnFDI}_{\mathrm{t}-4}$ & -32446.35 & $-4.25^{* * *}$ \\
\hline & $\Delta \ln Y a u s \mathrm{t}_{-4}$ & -11.96087 & $-2.22^{* *}$ & $\Delta \ln Y \operatorname{cin}_{\mathrm{t}-1}$ & 9557732. & $3.21^{* * *}$ & $\Delta \operatorname{lnFDI} I_{t-5}$ & -28968.49 & $-6.29^{* * *}$ \\
\hline & $\Delta \ln R E R$ & -4370.189 & $-2.45^{* *}$ & $\Delta \ln Y \operatorname{cin}_{t-2}$ & 7271789 & $2.91^{* *}$ & $\Delta \ln F I_{t-6}$ & -17089.23 & $-4.65^{* * *}$ \\
\hline & $\Delta \ln R E R_{t-5}$ & -5239.110 & $-3 \cdot 79^{* * *}$ & $\Delta \ln Y \operatorname{cin}_{\mathrm{t}-3}$ & 10426228 & $3.82^{* * *}$ & $\Delta \operatorname{lnNDS}$ & -37525.17 & $-3.18^{* * *}$ \\
\hline & & & & $\Delta \operatorname{lnYcin}_{\mathrm{t}-4}$ & 5315482. & 1.70 & $\Delta \operatorname{lnNDS}_{\mathrm{t}-4}$ & 28324.71 & $4.79^{* * *}$ \\
\hline & & & & $\Delta{\ln Y \operatorname{cin}_{\mathrm{t}-6}}$ & 9940037 & $4.29^{* * *}$ & $\Delta \operatorname{lnNDS} S_{t-6}$ & 21134.85 & $4.19^{* * *}$ \\
\hline & & & & $\Delta \ln Y \operatorname{cin}_{\mathrm{t}-7}$ & 11693981 & $4.04^{* * *}$ & $\Delta \operatorname{lnNDS}_{\mathrm{t}-7}$ & 24391.13 & $5.28^{* * *}$ \\
\hline & & & & $\Delta{\ln Y \operatorname{cin}_{\mathrm{t}-9}}$ & -9275433 & $-2.84^{* *}$ & $\Delta \operatorname{lnRER}$ & -7297100 & -1.59 \\
\hline & & & & $\Delta \ln Y \operatorname{cin}_{\mathrm{t}-1 \mathrm{o}}$ & -7255381 & $-3.05^{* * *}$ & $\Delta \ln R E R_{t-2}$ & -7477466 & $-1.99^{*}$ \\
\hline & & & & $\Delta \operatorname{lnFDI}$ & -60890.72 & $-4.92^{* * *}$ & $\Delta \ln R E R_{\mathrm{t}-6}$ & -7816264 & $-2.12^{* *}$ \\
\hline & & & & $\Delta \operatorname{lnFDI} I_{t-1}$ & -267729.5 & $-3.59^{* * *}$ & $\Delta \ln R R_{\mathrm{t}-7}$ & 9793011. & $3.01^{* * *}$ \\
\hline & & & & $\Delta \operatorname{lnFDI} I_{t-2}$ & -327467.9 & $-4.46^{* * *}$ & & & \\
\hline & & & & $\Delta \operatorname{lnFDI}_{\mathrm{t}-3}$ & -330930.6 & $-4.85^{* * *}$ & & & \\
\hline & & & & $\Delta \operatorname{lnFDI} I_{t-4}$ & -341591.9 & $-5 \cdot 74^{* * *}$ & & & \\
\hline & & & & $\Delta \operatorname{lnFDI} I_{t-5}$ & -350889.2 & $-6.06^{* * *}$ & & & \\
\hline & & & & $\Delta \operatorname{lnFDI} I_{-6}$ & -296396.9 & $-5.90^{* * *}$ & & & \\
\hline & & & & $\Delta \operatorname{lnFDI} I_{t-7}$ & -288736.9 & $-6.62^{* * *}$ & & & \\
\hline & & & & $\Delta \operatorname{lnFDI} I_{t-8}$ & -284738.1 & $-7.15^{* * *}$ & & & \\
\hline & & & & $\Delta \operatorname{lnFDI} I_{t-9}$ & -225209.5 & $-7.21^{* * *}$ & & & \\
\hline & & & & $\Delta \ln F I_{\mathrm{t}-10}$ & -96362.52 & $-5 \cdot 79^{* * *}$ & & & \\
\hline & & & & $\Delta \operatorname{lnNDS}$ & -141411.6 & $-3.24^{* * *}$ & & & \\
\hline & & & & $\Delta \ln \operatorname{NDS}_{\mathrm{t}-1}$ & -453517.5 & $-6.69^{* * *}$ & & & \\
\hline & & & & $\Delta \ln N S_{\mathrm{t}-2}$ & -494443.2 & $-7.24^{* * *}$ & & & \\
\hline & & & & $\Delta \operatorname{lnNDS}_{\mathrm{t}-3}$ & -289407.9 & $-6.52^{* * *}$ & & & \\
\hline & & & & $\Delta \operatorname{lnNDS}_{\mathrm{t}-5}$ & 253738.0 & $7.18^{\star * *}$ & & & \\
\hline & & & & $\Delta \operatorname{lnNDS} S_{t-6}$ & 275976.7 & $7.61^{* * *}$ & & & \\
\hline
\end{tabular}




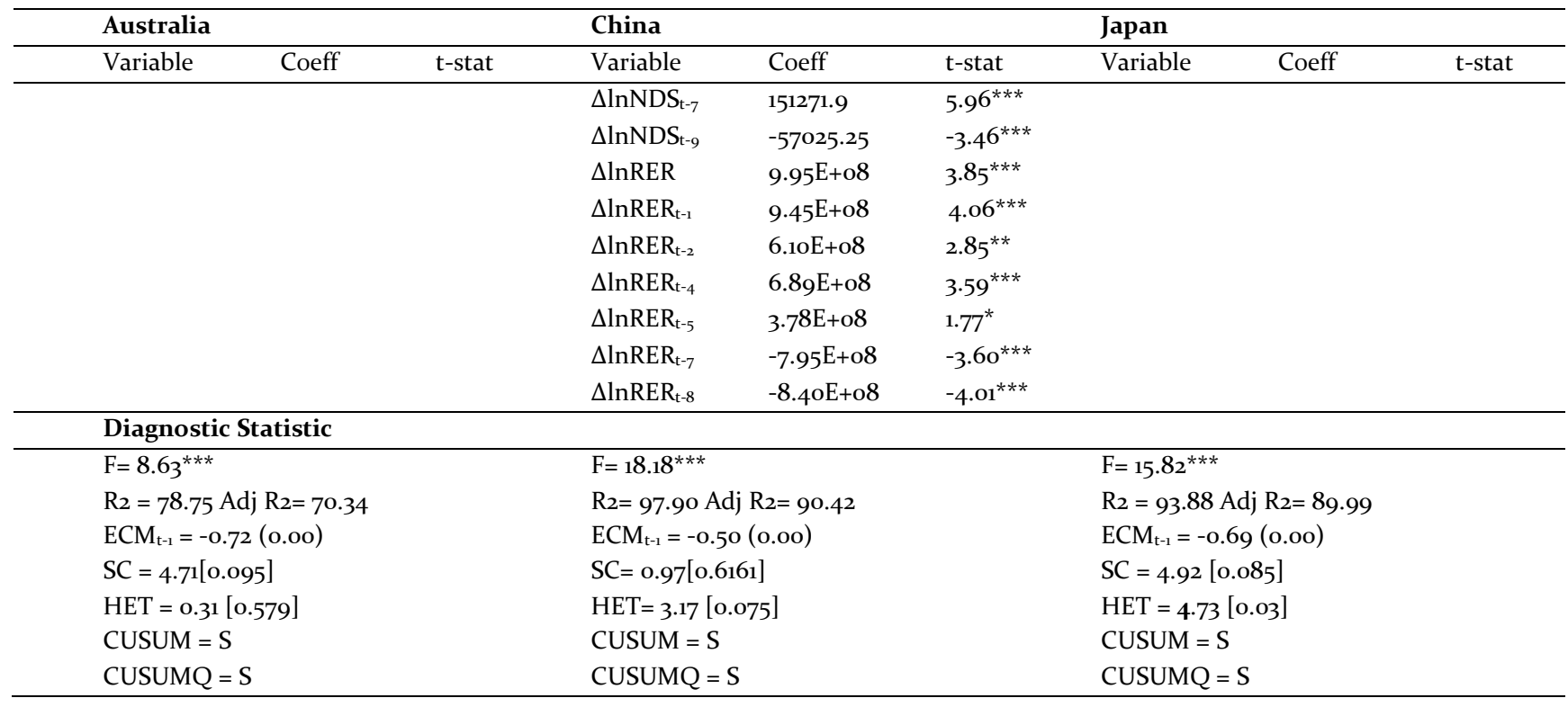

\section{Continued}

\begin{tabular}{|c|c|c|c|c|c|c|}
\hline & \multicolumn{3}{|l|}{ Malaysia } & \multicolumn{3}{|c|}{ Singapore } \\
\hline & Variable & Coeff & t-stat & Variable & Coeff & t-stat \\
\hline \multirow{12}{*}{ 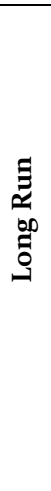 } & Constant & 1524841. & $1.76^{*}$ & Constant & 2749599. & $3 \cdot 34^{* * *}$ \\
\hline & $\ln \mathrm{TBT}_{\mathrm{t}-1}$ & -0.246791 & $-1.95^{*}$ & $\ln \mathrm{TBT}_{\mathrm{t}-1}$ & -0.778319 & $-6.43^{* * *}$ \\
\hline & $\operatorname{lnYidn}_{\mathrm{t}-1}$ & -1030602. & -1.14 & $\operatorname{lnYidn}_{\mathrm{t}-1}$ & 1685520. & $3.03^{* * *}$ \\
\hline & $\operatorname{lnYmay} t-1$ & 664140.1 & 0.69 & $\operatorname{lnYsgp} t-1$ & -2571220 . & $-3 \cdot 91^{* * *}$ \\
\hline & $\ln F D I_{t-1}$ & 11571.60 & 0.44 & $\operatorname{lnFDI} I_{t-1}$ & $51129 \cdot 55$ & $1.99^{*}$ \\
\hline & $\operatorname{lnNDS} S_{t-1}$ & 137757.9 & $2.15^{* *}$ & $\operatorname{lnNDS} S_{t-1}$ & $-19466.5^{2}$ & -0.76 \\
\hline & $\operatorname{lnRER}_{t-1}$ & $1.15 \mathrm{E}+09$ & $2.44^{* *}$ & $\operatorname{lnRER}_{\mathrm{t}-1}$ & $9.08 \mathrm{E}+08$ & 1.29 \\
\hline & LnYidn & -4176019. & -1.31 & LnYidn & 2165591 & $3.16^{* * *}$ \\
\hline & LnYmay & 2691109. & 0.77 & LnYsgp & -3303557 & $-4 \cdot 44^{* * *}$ \\
\hline & LnFDI & 46888.35 & 0.45 & LnFDI & 65692.31 & $1.91^{*}$ \\
\hline & LnNDS & $558197 \cdot 9$ & 1.43 & LnNDS & -25010.99 & -0.74 \\
\hline & LnRER & 4.64E+09 & 1.53 & LnRER & $1.71 E+09$ & 1.28 \\
\hline \multirow{14}{*}{ 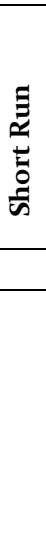 } & $\Delta \ln \mathrm{TBT}_{\mathrm{t}-1}$ & -0.249713 & -1.66 & $\Delta \operatorname{lnYidn}$ & 10592105 & $2.72^{* * *}$ \\
\hline & $\Delta \ln \mathrm{TBT}_{\mathrm{t}-2}$ & -0.224386 & -1.65 & $\Delta \operatorname{lnYidn}_{\mathrm{t}-1}$ & 7945297. & $1.87^{*}$ \\
\hline & $\Delta \operatorname{lnYidn}_{\mathrm{t}-1}$ & -18939441 & $-2.99^{* * *}$ & $\Delta \operatorname{lnYsgp}$ & -2567810 & $-2.44^{* *}$ \\
\hline & $\Delta \operatorname{lnNDS}$ & 77941.47 & $1.78^{*}$ & $\Delta \ln \operatorname{NDS}_{\mathrm{t}-1}$ & 477150.23 & $2.34^{* *}$ \\
\hline & & & & $\Delta \operatorname{lnFDI} I_{\mathrm{t}-1}$ & -56714.01 & $-2.65^{* *}$ \\
\hline & & & & $\Delta \ln \mathrm{FDI}_{\mathrm{t}-2}$ & $-24794 \cdot 37$ & -1.57 \\
\hline & \multicolumn{6}{|c|}{ Diagnostic Statistic } \\
\hline & \multicolumn{3}{|l|}{$F=3.24$} & \multicolumn{3}{|l|}{$\mathrm{F}=8.5^{* * *}$} \\
\hline & \multicolumn{3}{|c|}{$\mathrm{R}_{2}=47.66$ Adj $\mathrm{R} 2=35.19$} & \multicolumn{3}{|c|}{$\mathrm{R} 2=53.96$ Adj $\mathrm{R} 2=44.47$} \\
\hline & \multicolumn{3}{|c|}{$\mathrm{ECM}_{\mathrm{t}-1}=-0.31(0.03)$} & \multicolumn{3}{|c|}{$\mathrm{ECM}_{\mathrm{t}-1}=-0.76(0.00)$} \\
\hline & \multicolumn{3}{|c|}{$\mathrm{SC}=1.98[0.37]$} & \multicolumn{3}{|c|}{$\mathrm{SC}=1.32[0.517]$} \\
\hline & \multicolumn{3}{|c|}{$\mathrm{HET}=0.36[0.548]$} & \multicolumn{3}{|c|}{$\mathrm{HET}=2.61[0.106]$} \\
\hline & \multicolumn{3}{|c|}{ CUSUM = S } & \multicolumn{3}{|c|}{ CUSUM = S } \\
\hline & \multicolumn{3}{|c|}{ CUSUMQ $=\mathrm{S}$} & \multicolumn{3}{|c|}{ CUSUMQ = S } \\
\hline
\end{tabular}

Note : The long-run coefficients Ln is defined by $\hat{\beta}=-\hat{\theta} / \hat{\rho}$. Pesaran et al., (2001) tabulated the critical value of $\mathrm{F}$ bound test $5 \%$ for $\mathrm{k}=5$ as follows: Fcrit $=3.79,{ }^{* * *}: 1 \%,{ }^{*}: 5 \%,{ }^{*} 10 \%, \mathrm{~K}=6$ as follows: Frit $=3.61,{ }^{*}{ }^{*}: 1 \%,{ }^{*}: 5 \%,{ }^{*}: 10 \%$. SC, HET shows test LM evaluating against serial correlation, heteroskedasticity (ARCH). 
Critical value of the Pesaran, Shin \& Smith (2001) F stats in the linear ARDL model for five exogenous variables with unrestricted intercept and no trend are 2.26, 2.62 and 3.41 for lower bounds and 3.35, 3.79 and 4.68 for upper bound with significance levels of 10 percent, 5 percent and 1 percent. While in the model nonlinear ARDL for the 6 exogenous variables are 2.12, 2.45 and 3.15 for the lower bound and $3.23,3.61$ and 4.43 for the upper bound with the same level of significance. Based on empirical results shows that only Indonesia-Malaysia does not support long-term relationships while Indonesia-Australia, Indonesia-China, Indonesia-Japan and Indonesia-Singapore support long-term relationships in both the ARDL plus nonlinear ARDL linear models.

Based on the findings of the estimates from the ARDL linear model specification, the Indonesian income parameter value is positive in Australia, China and Singapore, but against Japan and Malaysia the Indonesian income coefficient is negative. In addition, negative partner countries ' revenue growth coefficient is Australia, China, Japan and Singapore. As for only Malaysia's positive income coefficient of growth. This result shows Indonesia's revenue growth increasing Indonesia's tourism trade balance to Australia, China and Singapore. Meanwhile, partner country's revenue growth worsened the Indonesian tourism trade balance with Australia, China, Japan and Singapore. The coefficient of Foreign Direct Investment (FDI) is positive in all partner countries, showing the FDI to improve Indonesia's tourism trade balance. Negative natural disaster coefficient in Indonesia-Japan and Indonesia-Singapore while other partner countries are positive. Subsequent coefficient of real rate of exchange (RER) which is the emphasis of the research is positively related in China, Malaysia and Singapore. However, we cannot determine that depreciation improves Indonesia's tourism trade balance because the coefficient is positive but not significant. This could give an idea that the effect of real exchange rates on the tourism trade balance is asymmetrical so that we continue testing using the nonlinear ARDL model in the table 3.

Several diagnostic tests are also reported in table 2 . The SC is the LM test for detecting serial correlation which shows no problem in serial correlation in all models. Similarly, HET (ARCH) does not show heteroscedasticity problems in all models except for the Indonesia-Japan relationship. To solve this problem, we use the Huber-White Standard Error Approach. CUSUM and CUSUMQ are used to test the stability of the estimation results and show that all models are stable. ECMt-1 shows the highest adjustment speed in Singapore $(-0.76)$ and is followed by Australia (-0.72), Japan (-0.69), China (-0.50) and Malaysia (-0.31).

Table 3. Nonlinear ARDL

\begin{tabular}{|c|c|c|c|c|c|c|c|c|c|}
\hline & Australia & & & China & & & Japan & & \\
\hline & Variable & Coeff & t-stat & Variable & Coeff & t-stat & Variable & Coeff & t-stat \\
\hline \multirow{8}{*}{ 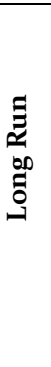 } & Constant & 17.62936 & 1.57 & Constant & -61613530 & $-6.34^{* * *}$ & Constant & 2939611. & 1.55 \\
\hline & $\ln \mathrm{TBT}_{\mathrm{t}-1}$ & -0.351147 & $-4.28^{* * *}$ & $\ln \mathrm{TBT}_{\mathrm{t}-1}$ & -1.111622 & $-9.63^{* * *}$ & $\ln \mathrm{TBT}_{\mathrm{t}-1}$ & -1.108644 & $-7.05^{* * *}$ \\
\hline & $\operatorname{lnYidn}_{\mathrm{t}-1}$ & 4.331010 & $3.14^{* * *}$ & $\operatorname{lnYidn}_{\mathrm{t}-1}$ & 19921871 & $7.63^{* * *}$ & $\operatorname{lnYidn}_{\mathrm{t}-\mathrm{I}}$ & 480309.2 & $1.76^{*}$ \\
\hline & $\operatorname{lnYaus}_{\mathrm{t}-1}$ & -7.109627 & $-2.35^{* *}$ & $\ln Y \operatorname{cin}_{t-1}$ & -7109323 & $-4.81^{* * *}$ & $\operatorname{lnYjpn}_{\mathrm{t}-1}$ & $-846507 \cdot 3$ & $-2.53^{* *}$ \\
\hline & $\operatorname{lnFDI} I_{t-1}$ & 0.001620 & 0.06 & $\operatorname{lnFDI} I_{t-1}$ & 211780.1 & $2.74^{* *}$ & $\operatorname{lnFDI} I_{t-1}$ & 5512.193 & 0.96 \\
\hline & $\operatorname{lnRER}^{+}{ }_{t-1}$ & 2226.584 & 1.23 & $\operatorname{lnRER}^{+}{ }_{\mathrm{t}-1}$ & $-4.40 E+09$ & $-5.12^{* * *}$ & $\operatorname{lnRER}^{+}{ }_{t-1}$ & 723038.7 & 0.17 \\
\hline & $\operatorname{lnRER}_{t-1}^{-}$ & 2304.363 & 0.98 & $\operatorname{lnRER}_{t-1}{ }$ & $1.09 \mathrm{E}+09$ & $3.42^{* * *}$ & $\operatorname{lnRER}_{t-1}$ & 18209107 & $3.19^{* * *}$ \\
\hline & LnYidn & 12.33388 & $4.02^{* * *}$ & LnYidn & 17921447 & $17.11^{* * *}$ & LnYidn & 433240.1 & $1.76^{*}$ \\
\hline
\end{tabular}




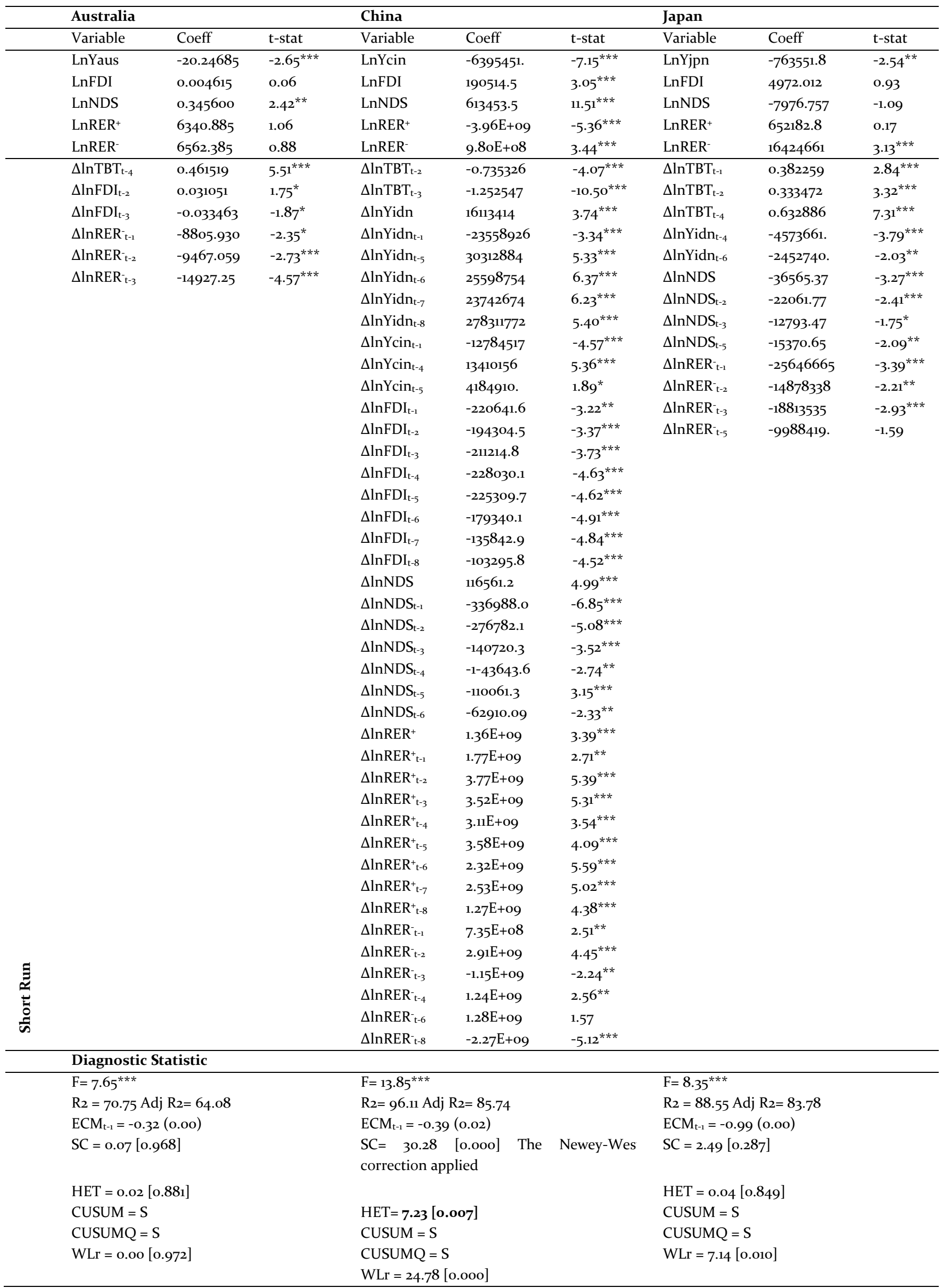




\section{Continued}

\begin{tabular}{|c|c|c|c|c|c|c|}
\hline & \multicolumn{3}{|l|}{ Malaysia } & \multicolumn{3}{|c|}{ Singapore } \\
\hline & Variable & Coeff & t-stat & Variable & Coeff & t-stat \\
\hline \multirow{14}{*}{ 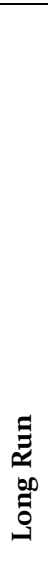 } & Constant & 13892.6 & 0.04 & Constant & 7418196. & $2.24^{* *}$ \\
\hline & $\ln \mathrm{TBT}_{\mathrm{t}-1}$ & -0.258609 & $-1.97^{*}$ & $\ln \mathrm{TBT}_{\mathrm{t}-1}$ & -0.820000 & $-6.66^{* * *}$ \\
\hline & $\operatorname{lnYidn}_{\mathrm{t}-1}$ & -529232.8 & -0.52 & $\operatorname{lnYidn}_{\mathrm{t}-\mathrm{I}}$ & 1188975 . & $1.72^{*}$ \\
\hline & $\operatorname{lnYmay}{ }_{t-1}$ & 520586.2 & 0.51 & $\operatorname{lnYsgp}_{t-1}$ & -3041107 & $-4.27^{* * *}$ \\
\hline & $\operatorname{lnFDI}{ }_{t-1}$ & 12443.84 & 0.45 & $\operatorname{lnFDI} I_{t-1}$ & 56163.81 & $2.18^{* *}$ \\
\hline & $\operatorname{lnNDS}{ }_{t-1}$ & 58042.96 & 1.23 & $\operatorname{lnNDS} \mathrm{t}_{\mathrm{t}-1}$ & -11292.85 & -0.44 \\
\hline & $\ln \operatorname{RER}^{+}{ }_{\mathrm{t}-1}$ & $1.23 \mathrm{E}+09$ & $2.19^{\star *}$ & $\ln \operatorname{RER}^{+}{ }_{t-1}$ & $9.96 \mathrm{E}+08$ & 1.31 \\
\hline & $\operatorname{lnRER}^{-}{ }_{t-1}$ & $1.57 \mathrm{E}+09$ & $1.96^{*}$ & $\operatorname{lnRER}^{-}{ }_{t-1}$ & $-9.17 E+08$ & -0.66 \\
\hline & LnYidn & -2046457 & -0.57 & LnYidn & 1449969. & $1.75^{*}$ \\
\hline & LnYmay & 2013022 & 0.56 & LnYsgp & -3708665 & $-4.91^{* * *}$ \\
\hline & LnFDI & 484118.31 & 0.46 & LnFDI & 68492.43 & $2.09^{* *}$ \\
\hline & LnNDS & 224442.6 & 1.05 & LnNDS & -13771.77 & -0.43 \\
\hline & LnRER $^{+}$ & $4 \cdot 76 \mathrm{E}+09$ & 1.45 & LnRER $^{+}$ & $1.21 E+09$ & 1.29 \\
\hline & LnRER $^{-}$ & $6.08 \mathrm{E}+09$ & 1.42 & LnRER $^{-}$ & $-1.12 \mathrm{E}+09$ & -0.66 \\
\hline \multirow{16}{*}{ 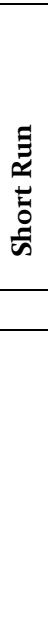 } & $\Delta \ln \mathrm{TBT}_{\mathrm{t}-\mathrm{I}}$ & -0.285413 & $-1.85^{*}$ & $\Delta \operatorname{lnYidn}$ & 10925826 & $2.83^{* * *}$ \\
\hline & $\Delta \ln \mathrm{TBT}_{\mathrm{t}-2}$ & -0.274995 & $-1.99^{*}$ & $\Delta \operatorname{lnYidn}_{\mathrm{t}-1}$ & 9094889. & $2.12^{* *}$ \\
\hline & $\Delta \operatorname{lnYidn}_{\mathrm{t}-1}$ & -21399381 & $-3.06^{* * *}$ & $\Delta \operatorname{lnYsgp}$ & -2782780 & $-2.56^{* *}$ \\
\hline & & & & $\Delta \ln F \mathrm{FI}_{\mathrm{t}-\mathrm{I}}$ & -60381.20 & $-2.83^{* * *}$ \\
\hline & & & & $\Delta \ln F I_{t-2}$ & -29641.04 & $-1.85^{* *}$ \\
\hline & & & & $\Delta \ln N D S_{\mathrm{t}-\mathrm{I}}$ & 47574.22 & $2.37^{* *}$ \\
\hline & & & & $\Delta \ln R^{\prime} R^{+}$ & $-2.44 \mathrm{E}+09$ & -1.37 \\
\hline & \multicolumn{6}{|c|}{ Diagnostic Statistic } \\
\hline & \multicolumn{3}{|c|}{$\mathrm{F}=2.24$} & \multicolumn{3}{|c|}{$\mathrm{F}=8.52^{* * *}$} \\
\hline & \multicolumn{3}{|c|}{$\mathrm{R}_{2}=43.89$ Adj $\mathrm{R}_{2}=30.54$} & \multicolumn{3}{|c|}{$\mathrm{R}_{2}=56.20$ Adj $R_{2}=45.25$} \\
\hline & \multicolumn{3}{|c|}{$\mathrm{ECM}_{\mathrm{t}-1}=-0.30(0.03)$} & \multicolumn{3}{|c|}{$\mathrm{ECM}_{\mathrm{t}-1}=-0.77(\mathrm{o} .00)$} \\
\hline & \multicolumn{3}{|c|}{$\mathrm{SC}=1.29[0.522]$} & \multicolumn{3}{|c|}{$\mathrm{SC}=0.32[0.850]$} \\
\hline & \multicolumn{3}{|c|}{$\mathrm{HET}=0.25[0.617]$} & \multicolumn{3}{|c|}{$\mathrm{HET}=1.28[0.258]$} \\
\hline & \multicolumn{3}{|c|}{ CUSUM = S } & \multicolumn{3}{|c|}{ CUSUM = S } \\
\hline & \multicolumn{3}{|c|}{ CUSUMQ = S } & \multicolumn{3}{|c|}{ CUSUMQ = S } \\
\hline & \multicolumn{3}{|c|}{$\mathrm{WLr}=0.13[0.722]$} & \multicolumn{3}{|c|}{$\mathrm{WLr}=1.85$ [0.179] } \\
\hline
\end{tabular}

Note : The long-run coefficients Ln is defined by $\hat{\beta}=-\hat{\theta} / \hat{\rho}$. Pesaran et al., (2001) tabulated the critical value of $\mathrm{F}$ bound test $5 \%$ for $\mathrm{k}=5$ as follows: Fcrit $=3.79,{ }^{* * *}: 1 \%,{ }^{*}: 5 \%,{ }^{*} 10 \%, \mathrm{~K}=6$ as follows: Frit $=3.61,{ }^{*} *: 1 \%,{ }^{* *}: 5 \%,{ }^{*}: 10 \%$. SC, HET shows test LM tests for serial correlation, heteroskedasticity (ARCH). WLr shows the Wald test for long-term symmetry.

Before interpreting the resulting Indonesia-Japan (WLr: 7.14) influence the coefficient of nonlinear ARDL estimation, we exchange rate against the trade balance are tested the cointegration between variables and showed that the entire model was co integrated except Indonesia-Malaysia. We then used test Wald to see symmetrical or asymmetric properties in the model. The test result of the Wald in the 1.3 table shows that only Indonesia-China (WLr: 24.78) and asymmetrical and should refer to the nonlinear ARDL coefficient. While Indonesia-Australia, Indonesia-Malaysia and Indonesia-Singapore are symmetrical that the influence of exchange rate is either depreciation or appreciation is equal to the Indonesian tourism trade balance and refers to the linear coefficient of ARDL. 
Thus, Indonesia-China and IndonesiaJapan will use the model nonlinear ARDL in interpreting its efficiency. The growth of Indonesian revenues increases Indonesia's tourism trade balance while China and Japan's revenue growth leads to a worsening of Indonesia's tourism trade balance as expected. The FDI coefficient is positive for both partners as expected. Natural disaster coefficient is positive for China and negative for Japan. This indicates that natural disasters will exacerbate Indonesia's tourism trade balance on Japan but not against China. Further focus of the research is the depreciation coefficient (lnRER-) positive and significant on both partners so that it can be concluded that the depreciation of real exchange rate can increase the balance of Indonesia's tourism trade on China and Japan in the long term. Besides only IndonesiaChina's significant negative appreciation coefficient which means appreciation worsens Indonesia's long-term tourism trade balance.

Several diagnostic tests were also reported in the 1.3 table. To solve the serial problem correlation in Indonesia-China the Newey-West correction is used. SC is an LM test to detect serial correlation indicating there is no problem in serial correlation in both models. Similarly, HET (ARCH) does not show heteroscedasticity problems in all models except the Indonesia-China relationship. CUSUM and CUSUMQ were used to test the stability of the estimated results and showed that the entire model was stable. In addition, ECMt-1 shows the highest adjustment speeds in Japan (-0.99) than in China (-0.39).

Next we want to test the J-curve phenomenon by using the definition of Bahmani-Ooskooee \& Fariditivana (2016): Where the J-curve phenomenon occurs if the short-term coefficient is negative or not statistically significant and the depreciation coefficient is long term positive and significant. For that we focus on the results of short- and long-term estimates where IndonesiaAustralia, Indonesia-Malaysia and IndonesiaSingapore use the ARDL linear model while Indonesia-China and Indonesia-Japan use the nonlinear ARDL model specification based on the outcome of Wald test of the symmetrical specification. From the results of the estimate, we found that the depreciation of real exchange rate worsens the trade balance in the short term and increases in the long term on Indonesia-China and Indonesia-Japan trade balance. Thus, we've found that there is a J-curve effect on the two countries.

The research focuses on the influence of depreciation and appreciation of real exchange rates on Indonesia's tourism trade balance of Australia, China, Japan, Malaysia and Singapore. The findings revealed that the weakening of real exchange rate affects Indonesia's tourism trade balance of China and Japan, where depreciation exacerbate the trade balance of tourism in the short term and increases in the long term in accordance with J-curve theory. It is in accordance with the findings of the Magee, (1973); Bahmani-Oskooee, (1985); Rose \& Yellen, (1989;) Bahmani-Oskooee \& Fariditavana, (2016) that stated the weakening of the rate of exchange exacerbated the balance sheet at first and increased it over time. However, we did not find the J-curve pattern on Indonesian-Australian relations due to negative but statistically significant and Indonesian-Malaysian and Indonesian-Singaporean coefficient due to positive coefficient but not statistically significant. Especially in Indonesia-Australia, it shows that the number of inbound and outbound in the long term is less than one or inelastic. So the condition of Marshall-Lerner does not apply during this period (Shah \& Majeed, 2014).

Our findings also proved that the influence of real exchange rates on Indonesia's tourism trade balance with Australia, Malaysia and Singapore is symmetrically and China and Japan are asymmetrical. This indicates either depreciation or appreciation has the same effect 
on the trade balance of Indonesia-Australia, Indonesia-Malaysia and Indonesia-Singapore but has different effect on Indonesian-Chinese and Indonesian-Japanese relations. Thus assuming the relation concerning rate exchange plus trade balance specified as symmetrical can result in false regression (Dogru, Isik, \& Sirakaya-Turk, 2019).

Furthermore, revenues have a role in increasing international traveler visits. Expected with increased revenues were able to push tourists decisions to do international vacations (Eugenio-Martin \& Campos-Soria, 2011). But in the case of Indonesian tourism only Malaysia where increased revenues are able to increase tourism demand in Indonesia. While the relationship between Indonesia and Australia, China, Japan and Singapore are thus lowering tourism demand. This is likely due to the tourists being more sensitive to the exchange rate compared to revenue (Dogru, Sirakaya-Turk \& Crouch, 2017).

The coefficient of FDI tourism sector is positive on all models of this research. It is that the greater the FDI inflows can increase the number of international tourist arrivals to a destination (Ravinthirakumaran, et al, 2019). As expected, FDI tourism sector is able to drive tourism demand through infrastructure developments such as hotels, restaurants, shopping centers, resorts, transportation, entertainment and recreation places. On the other hand, the natural disaster coefficient is negative towards Japan and Singapore but is positive for Australia, China and Malaysia. In some cases, natural disasters have a positive effect but generally negatively affect the visitor's visit after an event (Rosselló, Becken, \& Santana-Gallego, 2020). In addition, the perception of tourists will be the safety of the disaster to be one of the decision makers for sightseeing (Sharifpour, et al, 2014; Williams \& Baláž, 2015; Trumbo, et al, 2016). So it is important to build a perception of safety and after disaster to the public to attract and convince tourists to make vacations to the destination (World Travel \& Tourism Council, 2018).

\section{CONCLUSSION}

The purpose of this research is to investigate the effect of depreciation and appreciation of real exchange rates on the Indonesian tourism trade balance between Australia, China, Japan, Malaysia and Singapore. We use the linear ARDL and nonlinear ARDL approaches for that purpose. The ARDL nonlinear approach developed by Shin et al., 2014 allows testing different effects between the depreciation and appreciation of Indonesia's real exchange rate against the partner country. Assuming the relationship between exchange rate and trade balance is symmetrical can result in a biased estimate so it is necessary to consider the testing of data asymmetricity.

The results showed that the effect of real exchange rates on Indonesia's tourism trade balance was symmetrical against Australia, Malaysia and Singapore while being asymmetrical towards China and Japan. Thus, in interpreting the coefficient for Australia, Malaysia and Singapore we refer to the results of linear ARDL estimates whereas China and Japan refer to the results of nonlinear ARDL estimation. On a linear approach it reveals that Malaysian and Singaporean depreciation coefficient are positive but not statistically significant. Australian depreciation coefficient is negative and statistically significant indicating the number of import and export demand is inelastic. In addition, the nonlinear approach shows that Chinese and Japanese depreciation coefficient are positive and statistically significant. So, we confirm that the weakening of real rate of exchange will increase the balance of trade balance of Indonesia-China and Indonesia-Japan 
in the long term. Theoretically, the study also found evidence that the influence of real exchange rates on Indonesian-Chinese and Indonesian-Japanese tourism trade balance provides support for J-curve theory. Where initially depreciation worsened trade balance in the short term but increased in the long term (Bahmani-Oskooee, 1985; Rose \& Yellen, 1989; Bahmani-Oskooee \& Fariditavana, 2016). Finally, this study found that depreciation can increase tourism trade balance in particular Indonesia-China, where China is the largest outbound market in the world.

Some other variables such as income, FDI and natural disasters also influence tourist visits. However, the positive FDI coefficient on all models indicates that FDI can contribute to increasing tourist visits to Indonesia, so it is necessary to increase FDI to the tourism sector. It is also necessary for good disaster management to reduce the negative impact so that natural disasters have no impact on international tourist arrivals and do not interfere with the tourism industry in Indonesia.

Findings from this study also showed that governments should focus on the development of tourism industry so as to reduce trade balance deficit caused by global economic uncertainty. The Government should make special policies to countries with the largest inbound tourists to Indonesia in order to increase its visit. In addition, it is necessary to grant incentives such as tax relief and cheap credit awarding to the tourism industry to develop novel operations for instance hotels, resorts, amusement parks, plus various forms of tourism and hospitality establishments, to boost plus support stakeholders in the tourism business. It can also stimulate stakeholders to build a sustainable tourism industry that can spur national economic growth and minimize trade balance deficit.
Although the focus of this study examines the asymmetric effect of the exchange rate on Indonesia's tourism trade balance, it is possible that there are variables that can affect the tourism sector, but the researchers did not include them in the model. So, it is hoped that future researchers will include variables that can influence the tourism sector such as distance between countries, terror, visa-free policies, oil prices, hotel and restaurant taxes, and others.

\section{REFERENCES}

Agiomirgianakis, G., Bertsatos, G., \& Tsounis, N. (2018). Asymmetric responses in the tourism demand function, Journal of Economic Asymmetries. doi: 10.1016/j.jeca.2018.eoo103.

Ari, A., Cergibozan, R. \& Cevik, E. (2019). J-curve in Turkish bilateral trade: A nonlinear approach, International Trade Journal. doi: 10.1080/o8853908.2018.1521316.

Indonesian Central Statistics Agency (2019) Statistik Indonesia 2019, Katalog BPS.

Bahmani-Oskooee, M. (1985). Devaluation and the J-Curve: Some Evidence from LDCs, The Review of Economics and Statistics. doi: 10.2307/1925980.

Bahmani-Oskooee, M. \& Arize, A. C. (2019). U.S.Africa trade balance and the J-curve: An asymmetry analysis, International Trade Journal.

doi: 10.1080/o8853908.2019.1570881.

Bahmani-Oskooee, M., Economidou, C., \& Goswami, G. G. (2006). Bilateral J-curve between the UK vis-à-vis her major trading partners, Applied Economics. doi: 10.1080/00036840500399388.

Bahmani-Oskooee, M., \& Fariditavana, H. (2016) Nonlinear ARDL Approach and the JCurve Phenomenon, Open Economies Review. doi: 10.1007/s11079-015-9369-5.

Bahmani-Oskooee, M., Halicioglu, F. \& Hegerty, S. W. (2016). Mexican bilateral trade and the J-curve: An application of the 
nonlinear ARDL model, Economic Analysis and Policy. doi: 10.1016/j.eap.2016.02.003.

Bahmani-Oskooee, M., \& Harvey, H. (2019). The J-curve and bilateral trade balances of Indonesia with its major partners: are there asymmetric effects?, New Zealand Economic Papers. doi: 10.1080/00779954.2017.1371207.

Bahmani-Oskooee, M., \& Hegerty, S. W. (2010). The J- and S-curves: A survey of the recent literature, Journal of Economic Studies. doi: 10.1108/01443581011086639.

Bhati, A., Upadhayaya, A., \& Sharma, A. (2016). National disaster management in the ASEAN-5: an analysis of tourism resilience, Tourism Review. doi: 10.1108/TR-12-2015-0062.

Branson, W. H. (1972). The Trade Effects of the 1971 Currency Realignments, Brookings Papers on Economic Activity. doi: 10.2307/2534114.

Chen, Y. (2017). China's Tourism-Led Foreign Direct Investment Inflows: An Empirical Study, Modern Economy. doi: 10.4236/me.2017.81004.

Cheng, K. M., Kim, H. \& Thompson, H. (2013) The real exchange rate and the balance of trade in US tourism, International Review of Economics and Finance. doi: 10.1016/j.iref.2012.06.007.

Chi, J. (2015). Dynamic impacts of income and the exchange rate on US tourism, 1960-2011, Tourism Economics. doi: 10.5367/te.2014.0399.

Daniel, A. \& Rodrigues, P. M. M. (2011). Modelling Tourism demand in Portugal', Tourism Economics: Impact Analysis, 79-94.

Dogru, T., Isik, C., \& Sirakaya-Turk, E. (2019). The balance of trade and exchange rates: Theory and contemporary evidence from tourism, Tourism Management. doi: 10.1016/j.tourman.2019.01.014.

Dogru, T. \& Sirakaya-Turk, E. (2018). Modeling Turkish outbound tourism demand using a dynamic panel data approach, Tourism and Hospitality Research. doi: 10.1177/1467358416663822.

Dogru, T., Sirakaya-Turk, E., \& Crouch, G. I. (2017). Remodeling international tourism demand: Old theory and new evidence, Tourism Management. doi: 10.1016/j.tourman.2016.11.010.

Eugenio-Martin, J. L., \& Campos-Soria, J. A. (2011). Income and the substitution pattern between domestic and international tourism demand, Applied Economics. doi: 10.1080/oo036840903299698.

Huang, J. H. \& Min, J. C. H. (2002). Earthquake devastation and recovery in tourism: The Taiwan case, Tourism Management. doi: 10.1016/So261-5177(o1)ooo51-6.

Irandoust, M. (2019). On the relation between exchange rates and tourism demand: $\mathrm{A}$ nonlinear and asymmetric analysis, Journal of Economic Asymmetries. doi: 10.1016/j.jeca.2019.eoo123

Işik, C., Radulescu, M., \& Fedajev, A. (2019). The effects of exchange rate depreciations and appreciations on the tourism trade balance: The case of Spain, Eastern Journal of European Studies.

Karimi, M. S., Khan, A. A. \& Karamelikli, H. (2019). Asymmetric effects of real exchange rate on inbound tourist arrivals in Malaysia: An analysis of price rigidity, International Journal of Tourism Research, 21(2), 156-164. doi: $10.1002 /$ jtr.2249.

Loganatan, N. et al. (2019). The effects of exchange rate, price competitiveness indices and taxation on international 
tourism demand in Malaysia, Economics and Sociology. doi: 10.14254/2071-789X.2019/12-3/6.

Magee, S. P. (1973). Currency Contracts, PassThrough, and Devaluation, Brookings Papers on Economic Activity. doi: $10.2307 / 2534091$.

Mazzocchi, M. \& Montini, A. (2001) 'Earthquake effects on tourism in Central Italy', Annals of Tourism Research. doi: 10.1016/So16o7383(01)0ooo8-1.

Meo, M. S. et al. (2018). Asymmetric impact of oil prices, exchange rate, and inflation on tourism demand in Pakistan: new evidence from nonlinear ARDL, Asia Pacific Journal of Tourism Research. doi: 10.1080/10941665.2018.1445652.

Nash, D. (1981). Tourism as an anthropological subject, Current Anthropology. doi: 10.1086/202722.

Ongan, S. \& Özdemir, D. (2018). The Asymmetric Effects of Exchange Rates on the US Tourism Balances in the NAFTA Countries: An Application of The Nonlinear ARDL Approach, Journal of Applied Economics and Business Research JAEBR.

Peng, B. et al. (2015). A Meta-Analysis of International Tourism Demand Elasticities, Journal of Travel Research. doi: 10.1177/0047287514528283.

Pesaran, M. H., Shin, Y., \& Smith, R. J. (2001). Bounds testing approaches to the analysis of level relationships, Journal of Applied Econometrics. doi: 10.1002/jae.616.

Ravinthirakumaran, K. et al. (2019). Tourism and Foreign Direct Investment Inflows in Sri Lanka, South Asia Economic Journal. doi: 10.1177/1391561419858475.

Rose, A. K. \& Yellen, J. L. (1989). Is there a Jcurve?, Journal of Monetary Economics. doi: 10.1016/0304-
3932(89)90016-0.

Rosselló, J., Becken, S. \& Santana-Gallego, M. (2020). The effects of natural disasters on international tourism: A global analysis, Tourism Management. doi: 10.1016/j.tourman.2020.104080.

Serra, J., Correia, A., \& Rodrigues, P. M. M. (2014). A comparative analysis of tourism destination demand in Portugal, Journal of Destination Marketing and Management. doi: 10.1016/j.jdmm.2013.10.002.

Shah, A. \& Majeed, M. T. (2014). Real Exchange Rate and Trade Balance in Pakistan: An ARDL Co-integration Approach, MPRA Paper No. 57674.

Sharifpour, M. et al. (2014). Investigating the Role of Prior Knowledge in Tourist Decision Making: A Structural Equation Model of Risk Perceptions and Information Search, Journal of Travel Research. doi: 10.1177/o04728751350039o.

Shin, Y., Yu, B. \& Greenwood-Nimmo, M. (2014). Modelling Asymmetric Cointegration and Dynamic Multipliers in a Nonlinear ARDL Framework, in Festschrift in honor of Peter Schmidt, 281-314.

Surugiu, C., Leitão, N. C., \& Surugiu, M. R. (2011) 'A Panel data modelling of international tourism demand: Evidences for Romania, Ekonomska Istrazivanja. doi: 10.1080/1331677X.2011.11517450.

Tang, J. et al. (2016). Modelling dependence between tourism demand and exchange rate using the copula-based GARCH model, Current Issues in Tourism. doi: 10.1080/13683500.2014.932336.

Tribe, J. (2009) Philosophical issues in tourism, Philosophical Issues in Tourism. doi: 10.1016/j.tourman.2010.05.002.

Trumbo, C. W. et al. (2016). A Cognitive-Affective Scale for Hurricane Risk Perception, Risk Analysis. doi: 10.1111/risa.12575.

Tung, L. T. (2019). Does exchange rate affect the foreign tourist arrivals? Evidence in an 
emerging tourist market, Management Science Letters. doi: 10.5267/j.msl.2019.5.001.

Wang, L. \& Tang, X. (2018). Does RMB exchange rate volatility affect Beijing's inbound tourism development?, in 2018 4th International Conference on Information Management, ICIM 2018. doi: 10.1109/INFOMAN.2018.8392836.

Weisath, L., Knudsen, Ø., \& Tonnessen, A. (2002) 'Technological disasters, crisis management and leadership stress, in Journal of Hazardous Materials. doi: 10.1016/So304-3894(02)0o036-5.

Williams, A. M. \& Baláž, V. (2015). Tourism Risk and Uncertainty: Theoretical Reflections, Journal of Travel Research. doi: 10.1177/0047287514523334.

World Travel \& Tourism Council (2018) Travel $\mathcal{E}$ Tourism Economic Impact 2018 World, Travel and Tourism Impact 2018. doi: 10.1093/elt/ccro29.

World Travel \& Tourism Council - WTTC (2019) 'Travel and tourism: world economic impact 2019', Current Issues in Tourism. doi: 10.2167/cit/mpoo4.o.

WTTC (2016) Travel E Tourism In ASEAN. 